\section{Council for 2017/2018}

\section{President}

S. Ndlovu

President Elect

A.S. Macfarlane

Vice Presidents

$\begin{array}{ll}\text { Senior } & \text { Junior } \\ \text { M.I. Mthenjane } & \text { Z. Botha }\end{array}$

\section{Immediate Past-President}

C. Musingwini

\section{Honorary Treasurer}

V.G. Duke

\section{Members of Council}

V.G. Duke
I.J. Geldenhuys
M.F. Handley
W.C. Joughin
E. Matinde
M. Motuku
D.D. Munro

G. Njowa

S.M. Rupprecht

A.G. Smith

M.H. Solomon

D. Tudor

D.J. van Niekerk

A.T. van Zyl

\section{Branch Chairpersons}

$\begin{array}{ll}\text { Botswana Branch } & \text { L.E. Dimbungu } \\ \text { DRC Branch } & \text { S. Maleba } \\ \text { Johannesburg Branch } & \text { J.A. Luckmann } \\ \text { Namibian Branch } & \text { N.M. Namate } \\ \text { Northern Cape } & \text { W.J. Mans } \\ \text { Pretoria Branch } & \text { R.J. Mostert } \\ \text { Western Cape Branch } & \text { R.D. Beck } \\ \text { Zambian Branch } & \text { D. Muma } \\ \text { Zimbabwean Branch } & \text { S. Matutu } \\ \text { Zululand Branch } & \text { C.W. Mienie }\end{array}$

Past Presidents serving on Council
N.A. Barcza
R.G.B. Pickering
R.D. Beck
S.J. Ramokgopa
J.R. Dixon
M.H. Rogers
M. Dworzanowski
D.A.J. Ross-Watt
H.E. James
G.L. Smith
R.T. Jones
W.H. van Niekerk
G.V.R. Landman
R.P.H. Willis

\section{Key objectives of the Institute}

To initiate and give effect to the means whereby the requirement for technology and scientific knowledge of the minerals and metals section of the southern African economy is satisfied; and to represent and promote the interests of its members.

\section{Arrangement of this Report}

In accordance with the current management policy, this report on the activities of the Institute is presented under eight main headings:

1. Interests of Individual Members

2. Technical Meetings

3. Publications

4. Regional Development

5. Engineering Science and Technology in South Africa

6. State Liaison

7. International Liaison

8. Management and Administration.

\section{Interests of Individual Members}

\section{Portfolio Holder: S. Ndlovu}

J.R. Dixon, Chairperson

As at the end of the 2018 year, total membership across all categories stood at 5077 representing a slight decrease $(-4)$ year on year (Table 1). A total of 3608 are based in South Africa and a further 1084 from our Regional Branches in Southern Africa where healthy growth was seen in DRC and Zimbabwe (Table 2). The balance is made up of members scattered across the globe. The decrease in Members is reflective of the South African mining industry with more unemployment in technical occupations and people moving either into alternative industries in South Africa or moving internationally.

Student membership again showed robust growth increasing by 246 or $15.7 \%$ year on year with students now making up 36\% of total membership. The focus on our youth and Young Professionals remains a cornerstone strategy for the long-term health of the Institute. Council continues to

\section{Table I}

\section{Total SAIMM Membership Analysis by year on year}

\begin{tabular}{|l|c|c|c|}
\hline Membership grade & $\begin{array}{c}\text { Figure end of } \\
\mathbf{2 0 1 6 / 2 0 1 7}\end{array}$ & $\begin{array}{c}\text { Figure end } \\
\mathbf{2 0 1 7 / 2 0 1 8}\end{array}$ & $\begin{array}{c}\text { Net Gain/ } \\
\text { Loss }\end{array}$ \\
\hline Honorary Life Fellow & 49 & 49 & 0 \\
Honorary Fellow & 2 & 2 & 0 \\
Life Fellow & 7 & 7 & 0 \\
Fellow & 385 & 351 & -34 \\
Retired Fellow & 153 & 172 & 19 \\
Life Member & 1 & 1 & 0 \\
Member & 1678 & 1541 & -137 \\
Retired Member & 103 & 122 & 19 \\
Associate & 1010 & 910 & -100 \\
Retired Associate & 12 & 12 & 0 \\
Student & 1564 & 1810 & 246 \\
Company Affiliate & 117 & 100 & -17 \\
\hline Total & 5081 & 5077 & -4 \\
\hline
\end{tabular}




\begin{tabular}{|c|c|c|c|}
\hline Country Branches & 2016/17 & 2017/18 & \\
\hline Botswana & & 79 & 74 \\
\hline DRC & & 28 & 76 \\
\hline Namibia & & 91 & 63 \\
\hline Zambia & & 196 & 186 \\
\hline Zimbabwe & & 609 & 685 \\
\hline Total & & 1003 & 1084 \\
\hline
\end{tabular}

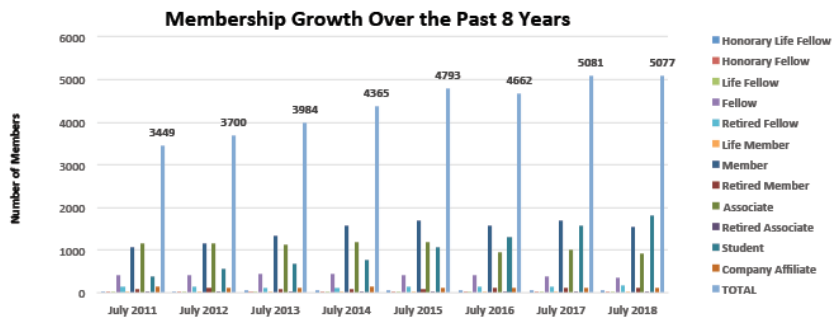

Graph 1-South African Membership Annual Growth

encourage the initiative of offering support to our members that are financially stressed, either through deferred fees or in exceptional cases, by waiving the annual fee. The number of people receiving this assistance is $1.02 \%$ compared with $0.59 \%$ last year which reflects the continuing pressure facing our membership in the mining industry.

Progress on the work of the Membership Committee includes the following activities:

> On-going updates of membership By-laws:

The criteria for acceptance as a Fellow has been reviewed to take account of the globalisation of the mining industry and movement of professionals from continent to continent. The new By-law will be presented to Council early in the 2018/2019 year;

> Actively focusing on upgrading members to higher membership grades:

This is an on-going task. Current focus is on Associates who have been at this grade of membership for more than 4 or 5 years. The membership committee have suggested to Council that this task be automated.

$>$ Re-design of the SAIMM web site to further improve application and payment efficiency:

> Recognising our newly elected Fellows at the annual banquet:

\section{Completed and on-going}

> Creating an electronic membership archive which enables monitoring of categories of membership and payment details by Branch:

On-going

> Two members of the YPC have been co-opted to the membership committee with the objective of connecting with Student and Associates and improving the conversion rate to Member status.

It is with great sadness that we have to report the passing of many of our members, many whom have played pivotal roles in the Southern African Mining and Metallurgical industries.

\begin{tabular}{|l|c|c|c|}
\hline \multicolumn{4}{|l|}{ Members who sadly passed on during 2017/2018 } \\
\hline Deceased & $\begin{array}{c}\text { Election } \\
\text { date }\end{array}$ & $\begin{array}{c}\text { Membership } \\
\text { number }\end{array}$ & Grade \\
\hline Kevin McMillan & 16 May 2014 & 706677 & Member \\
\hline John Myles Fowlds & $\begin{array}{c}6 \text { August } \\
1968\end{array}$ & 2615 & $\begin{array}{c}\text { Retired } \\
\text { Member }\end{array}$ \\
\hline Miklos Salamon & 6 June 1974 & 19652 & Member \\
\hline Rendani Sirwali & 21 October & 705383 & Associate \\
\hline Deirdre Jane Bradshaw & 15 May 1998 & 701738 & Member \\
\hline Oskar Kurt Helmut Steffen & 7 February & 10978 & $\begin{array}{c}\text { Honorary Life } \\
\text { Fellow }\end{array}$ \\
\hline
\end{tabular}

\begin{tabular}{|c|c|c|c|c|c|c|c|c|}
\hline \multicolumn{9}{|c|}{$\begin{array}{l}\text { Summary of membership for } 2017 / 2018 \text { and comparison of membership grades and } \\
\text { total membership from } 2011-2018\end{array}$} \\
\hline Membership grade & July 2011 & July 2012 & July 2013 & July 2014 & July 2015 & July 2016 & July 2017 & July 2018 \\
\hline Honorary Life Fellow & 34 & 36 & 54 & 53 & 53 & 51 & 49 & 49 \\
\hline Honorary Fellow & 3 & 3 & 2 & 2 & 1 & 2 & 2 & 2 \\
\hline Life Fellow & 9 & 7 & 7 & 7 & 7 & 7 & 7 & 7 \\
\hline Fellow & 420 & 421 & 429 & 434 & 412 & 398 & 385 & 351 \\
\hline Retired Fellow & 137 & 130 & 125 & 123 & 140 & 144 & 153 & 172 \\
\hline Life Member & 1 & 1 & 1 & 1 & 1 & 1 & 1 & 1 \\
\hline Member & 1075 & 1169 & 1334 & 1584 & 1702 & 1572 & 1678 & 1541 \\
\hline Retired Member & 97 & 99 & 92 & 94 & 96 & 102 & 103 & 122 \\
\hline Associate & 1148 & 1146 & 1132 & 1173 & 1176 & 961 & 1010 & 910 \\
\hline Retired Associate & 13 & 13 & 13 & 12 & 12 & 12 & 12 & 12 \\
\hline Student & 380 & 549 & 672 & 754 & 1069 & 1295 & 1564 & 1810 \\
\hline Company Affiliate & 132 & 126 & 123 & 128 & 124 & 117 & 117 & 100 \\
\hline Total & 3449 & 3700 & 3984 & 4365 & 4793 & 4662 & 5081 & 5077 \\
\hline
\end{tabular}




\section{Geographical distribution of membership, 2017/2018}

\begin{tabular}{l|c||l|c|}
\hline Country & Members & Country & Members \\
\hline Australia & 76 & Mongolia & 1 \\
\hline Austria & 2 & Mozambique & 8 \\
\hline Belgium & 4 & Namibia & 63 \\
\hline Botswana & 74 & Netherlands & 4 \\
\hline Brazil & 10 & New Zealand & 2 \\
\hline Cameroon & 1 & Nigeria & 2 \\
\hline Canada & 28 & Papua New Guinea & 1 \\
\hline Cayman Islands & 1 & Peru & 7 \\
\hline Chile & 8 & Philippines & 1 \\
\hline Colombia & 1 & Russia & 1 \\
\hline DRC & 76 & Rwanda & 1 \\
\hline Dominican Republic & 0 & Singapore & 1 \\
\hline Finland & 4 & South Africa & 3608 \\
\hline France & 4 & Suriname & 2 \\
\hline Germany & 6 & Swaziland & 4 \\
\hline Ghana & 88 & Sweden & 1 \\
\hline Hong Kong & 1 & Switzerland & 2 \\
\hline India & 8 & Tanzania & 13 \\
\hline Indonesia & 1 & Thailand & 2 \\
\hline Iran & 1 & Turkey & 5 \\
\hline Ireland & 3 & United Arab Emirates & 1 \\
\hline Israel & 2 & UK & 20 \\
\hline Lesotho & 2 & Venezuela & 42 \\
\hline Madagascar & Zambia & 186 \\
\hline Mauritius & & Total & 685 \\
\hline
\end{tabular}

In addition to membership growth, fee collection has remained a focus for the committee. Maintenance of contact with members remains a challenge. Membership and conference fees have been maintained well below inflation parameters to ensure that our members continue to get value for their fees. Unfortunately, it is expected that annual increases will need to be more aligned with cost increases in the coming years.

Maintaining a quorum at the Membership Committee has proved a challenge in the past year despite tele-conferencing. In the coming year thought will be given as to how the process can be further streamlined.

I wish to extend my personal thanks to the members of the Committee for their commitment and support during the past year.

\subsection{Membership Committee}

J.R. Dixon, Chairperson
N.A. Barcza
R.D. Beck
J.A. Cruise
G.V.R. Landman
D.A.J. Ross-Watt
G.V.R. Land Ngoma
G.L. Smith
T.R. Stacey
O.K.H. Steffen
R.G.B. Pickering
J.N. van der Merwe
D.J. van Niekerk
S.J. Ramokgopa
M. Woodhall

M.H. Rogers

\section{Membership}

The SAIMM membership comprises engineers, metallurgists, chemists, physicists, geologists, certificated managers, and technikon diplomates, and other disciplines, all of whom have an interest in the fields of mining, extractive metallurgy, metals technology, and other related areas.

\section{Requirements for Corporate membership}

Honorary Life Fellow: An Honorary Life Fellow shall be a person whom the Institute specifically desires to honour in consideration of services rendered to the Institute, to science, or to industry. Honorary Life Fellows shall have all the privileges of Corporate Members.

> The election of an Honorary Life Fellow shall take place at a Council meeting, due notice having been given at the preceding Council meeting of Council's intention to nominate a person as an Honorary Life Fellow. The election shall require the majority vote of Corporate Members of Council present at a Council meeting

> The election of an Honorary Life Fellow shall be announced at the following Annual General Meeting of the Institute

$>$ An Honorary Life Fellow will have all membership fees and subscriptions waived.

FeLLow: A candidate for admission to or transfer into the category of Fellow shall:

$>$ Be at least 35 (thirty-five) years of age

- Have, for a period of at least 5 (five) years, been practising in a senior technical position in mining or metallurgical undertakings, or in governmental, educational, or research organizations concerned with those industries, or

> Have, for a period of at least 5 (five) years, been practising as a consultant in the skills of mining and metallurgy, and

$>$ Be practising his/her profession at the time of application, satisfy Council that he/she is a fit and proper person to become a Fellow, and Council shall be satisfied that his/her qualifications, training, and technical experience justify such professional status, and

- Have been a Member of good standing for 5 (five) years and have promoted the interests of the SAIMM through:

- Serving on committee structures, and/or

- Publishing in the SAIMM Journal or conference proceedings, and/or

- By other means acceptable to Council.

MEMBER: A candidate for admission to or transfer into the category of Member shall:

> Be at least 25 (twenty-five) years of age

- Have, for a period of at least 2 (two) years, been practising in a responsible or senior technical position in minerals and metals industry undertakings or in governmental, service, educational, or research organizations concerned with those industries, or

> Have, for a period of at least 2 (two) years, been practising as a consultant in the minerals and metals industries, and

- Be practising his/her profession at the time of his/her application, satisfy Council that he/she is a fit and proper person to become a Member, and Council shall be satisfied that his/her qualification, training, and technical experience justifies such professional status. 
the mining and metallurgical industries are eligible for admission to the category of Company Affiliate.

HoNoRARy FELLow: Honorary Fellows shall be persons of distinction in public service, science, or the arts and shall be elected or re-elected by Council for the current year. They shall enjoy all the privileges and rights of members, except those of holding office and voting.

Associate: A candidate for admission into the category of Associate shall:

$>$ Be at least 18 (eighteen) years of age, and

> Be involved in minerals and metals industry undertakings or in governmental, service, educational, or research organizations concerned with those industries, but not meet requirements to be registered as a Corporate Member

> Satisfy Council that he/she is a fit and proper person to become an Associate Member.

STUDENT: A candidate for admission into the category of Student shall:

> Be a person in the third or further year of being educated or trained in a manner approved by Council to occupy a technical position or associated with the minerals or metals industries

> Satisfy Council that he/she is a fit and proper person to become a Student Member

> Remain a Student Member only while he/she is being educated in a manner approved by Council

> Confirm their membership at the beginning of each academic year by submitting proof of registration at their applicable tertiary institution. Failure to submit proof of registration will result in termination of membership

$>$ Not remain a Student Member after the end of the Institute's financial year in which he/she attains the age of 28 (twenty-eight) years. Council may relax the provisions of this clause in such cases as it considers appropriate.

\section{Membership roll}

Members of the Institute are divided into Corporate and NonCorporate Members, all of whom are entitled to attend and speak at meetings. Only Corporate Members are entitled to vote. All applications for membership or transfer require one proposer and one seconder.

ResignATION: A Member may resign from the Institute by sending his or her written resignation to the Secretary together with payment of any monies due.

RetiRed Membership: A Fellow or Member who has bona fide retired from active business may retain membership at a reduced subscription providing he or she has been a member for 20 years. Members can contact the Secretary to establish the number of years of service prior to submitting a written request for Retired Membership to the Institute.

STUDENTS: A candidate may remain a Student Member only while he or she is being educated or trained in a manner approved by the Council.

When he or she no longer qualifies as a Student Member, he or she shall automatically be transferred to the category of
Associate. Students are reminded to forward a copy of their degree certificates to the Institute on graduation.

A candidate may not remain a Student Member after the end of the Institute's financial year in which he or she attains the age of twenty-eight years, unless the Institute receives written confirmation from the university or technikon that the Student Member is still a full-time student.

Change of Details: It is essential that members contact the Institute without delay about change in designation, change in employer, payment address, or change in postal address. Without this the communication link to members is broken. Also, members must ensure that, where subscriptions are paid by a company, the Institute has on record the correct payment address.

\section{Benefits of membership}

Individuals derive various benefits from membership of the Institute:

> Contact with fellow members

> Special reduced fees when attending congresses, symposia, colloquia, conferences, schools, discussion groups, etc.

> Notices of events promoting technology transfer, which also satisfy the need for continuing education

- A monthly Journal with a balanced content and of high technical standard, which serves as a communication medium to keep members informed on matters relating to their professional interests

> Participation in technical excursions, banquets, and other social events, which create further opportunities for professional association and fellowship

> Tax deduction of membership fees in most cases

> Reduced registration fees for professional registration through the Engineering Council of South Africa.

Companies that become Members of the Institute:

> Benefit from the opportunities to exchange knowledge, particularly about new developments and research

> Receive the Institute's publications of international conferences held in South Africa, as well as monographs on a variety of subjects and regular copies of the monthly Journal

> Are entitled to send two non-member employees to mining and metallurgical schools, colloquia, congresses, visits, and excursions at member rates

> Receive newsletters and notices about all Institute activities

> Benefit from the fact that Company Affiliateship is tax deductible

> Have ample opportunity to send delegates to attend technical meetings to obtain information and to benefit from the experience of others.

\subsection{Young Professionals Council}

A.S. Nhleko, Chairperson

K.M. Letsoalo Vice Chairperson

T.M. Mmola, Immediate Past President

N. Tshiongo-Makgwe, Secretary

G. Dabula, Treasurer 


$\begin{array}{ll}\text { A.T. Chinhava } & \text { M. Mogalanyane } \\ \text { D.E.P. Klenam } & \text { R.P. Molehe } \\ \text { L.T. Lumbwe } & \text { K. Nnyenyiwa } \\ \text { T. Mahomedy } & \text { G. Nxumalo } \\ \text { S.F. Manjengwa } & \text { K. Shame } \\ \text { G. Marape } & \text { F. Uahengo } \\ \text { Z. Maruma } & \\ \text { Observers } & \\ \text { I.J. Geldenhuys } & \text { S.M. Rupprecht } \\ \text { S. Ndlovu } & \end{array}$

Strategy Focus for 2017-2018

In the 2017-2018 term the main strategy of the Young Professionals Council (YPC) was to initiate YPC activities in different regions where the Institute has branches and thus continue furthering the mandate of the SAIMM. The YPC was successful in taking significant steps to engage young professionals in Zimbabwe and Namibia.

The YPC also developed strategic guiding documents for portfolios and related action plans. The portfolios are Membership, Technical Programme Committee, Publications, Funding, Strategic Partnership, Advocacy, and Marketing.

\section{Zimbabwe}

YPC Zimbabwe (YPC-Zim) presented at the Zimbabwe Branch Conference 2017, which was the first activity of YPC-Zim. Institutional visits followed, resulting in the launching of student chapters, student recruitment, and engagement. As of June 2018, over 400 student applications had been submitted to the SAIMM head office in Johannesburg.

YPC-Zim also facilitated the participation of a student from Zimbabwe for the first time at the Student Colloquium 2017, who happened to be the runner-up in the mining category. Later that year, two associate members joined the YPC Committee, Audrey Mabiza and Mati Nemasasi. In 2018, a partnership with IOM3 was formed to start a Young Person's Lecture Competition in Zimbabwe. The event was held on 7 June, and three student finalists proceeded to represent Zimbabwe in the regional competitions. One of the students won the regional competition and will be representing Africa at the World Finals. An agreement is being negotiated with the University of Zimbabwe to have the competition held annually.

As of late, YPC-Zim has given one keynote presentation at one of the institutions. Other programmes lined up for the 2018-2019 year are student exchange programmes and student debating competitions. The Champion of the YPC-Zimbabwe Branch is Mr. Adrian Chinhava.

\section{Namibia}

The YPC-Namibia branch visited the UNAM José Eduardo Dos Santos Campus in the northern region of Namibia to give its first promotional presentation in the country. The aim of the visit was to promote the YPC and SAIMM among the students and staff at the UNAM campus. The presentation took place on 8 May 2018 and was attended by over 30 personnel and students. In addition to the presentation at the UNAM Campus, a stakeholders' dinner was held in Otjiwarongo in order to arrange the next roadshows in that town. The Champion of the YPC-Namibia Branch is Ms Foibe DL Uahengo.

\section{YPC Activities}

During the term, the YPC organized several events, which the YPC sees as being important in developing young professionals in general and in developing the capacity to deliver on the needs of the young professional members of the Institute.

\section{Education Working Group}

The YPC continues to support initiatives that focus on attracting learners to fields of study associated with the minerals industry. The YPC participated in the Sci-Bono Career Guidance events, giving career guidance to high school students. The YPC also ran a raffle at the SAIMM Banquet to raise funds for the Scholarship Trust Fund.

The Education Working Group (EWG) of the YPC was involved in hosting soft skills workshops at the University of Johannesburg (UJ), the University of the Witwatersrand (Wits), University of South Africa (UNISA), and University of Pretoria (UP). Topics included research and innovation, time management, interview skills, curriculum vitae writing, and presentation skills. Workshops planned for the remainder of the 2018 academic year include personal branding, financial skills, and entrepreneurship. The purpose of these workshops is to prepare well-rounded graduates for the minerals industry.

On 24 August 2017, mining and metallurgy students from UJ and Wits participated in the annual student debate, with the theme 'The Future of Artisanal and Small-Scale Mining in the South African Mining Industry'. The debate was co-hosted by the SAIMM Johannesburg Branch and the YPC.

On 5 August 2017 the YPC, in partnership with students bodies from UP and UNISA, hosted the Careers and Leadership Conference held at the University of Pretoria. Students from Wits, UJ, UP, and UNISA were in attendance.

The SAIMM held the Annual Student Colloquium on 25 October 2017 at Mintek. The special student edition of the Journal was published in April 2018, containing papers from the top five students.

In June 2018, the YPC published a second edition of the emagazine Youth in Mining and Metallurgy (YIMM). The e-magazine was fully authored by university students and covers topics that matter to the student population.

\section{Career Guidance Working Group}

The YPC has initiated the development of a Graduate Development Programme for mining and metallurgical graduates. Once the programme is ready, it will be circulated for comments. The YPC and SAIMM Johannesburg Branch cohosted a technical presentation by Maptek, titled 'Maptek innovative mining technology' at Worley Parsons on 24 May 2018. The YPC also organized site visits to mining operation and equipment manufacturers such as Komatsu.

\section{Enterprise Working Group}

The Enterprise Working Group is mainly focused on ensuring that young professionals within the SAIMM have a full appreciation of the mining value chain. The working group provides opportunities for young professionals through seminars and conferences. A mining entrepreneurs conference was held in 2017-2018. The conference, entitled 'Entrepreneurship in Mining Forums', was a success and well attended across the board. The next entrepreneurship in mining 
conference has been tentatively earmarked for May 2019, with smaller events to be hosted in the lead-up to the main event.

\section{Mentorship Programme}

The YPC mentoring programme is in its third year of running. There are 40 protégés and 40 mentors participating in the 2018 programme. The programme allows young professionals to build connections with experienced practitioners and to develop into future leaders of the industry.

\section{Graduate Employment Database}

The YPC is sensitive to the challenge faced by young professionals to find meaningful and gainful employment in the minerals industry. Over 400 SAIMM members have registered on the Graduate Employment Database (GED) and the SAIMM sends out regular communication to these members alerting them on career, internship, or education opportunities. During the 2017-2018 term, six internship, career, and education opportunities were e-mailed through the database.

\section{Social media activity}

The SAIMM social media presence has grown extensively over the past financial year. The Facebook following has increased from 1876 to 2971 . Around $63 \%$ of the Facebook following comprises young professionals in the industry who are 35 years of age and younger. The Twitter following has grown from 1430 to 1700 over the past year. An Instagram account was created for the YPC in January 2018, and the profile currently has 199 followers, with an increase expected in the forthcoming year. LinkedIn has seen the highest growth in followers over the year 2017-2018. At the beginning of the financial year the SAIMM had 646 followers, and ended the year with 4256 followers, $34 \%$ of whom are entry-level professionals in the industry. The SAIMM YouTube channel currently has 11 subscribers.

\subsection{Promotion of the SAIMM}

\section{Portfolio holder: S. Ndlovu}

The 2017/2018 financial year was characterized by a host of activities and initiatives organized by the Institute and supported by a slowly recovering global mining industry. The SAIMM continued to implement strict measures to absorb as much of the financial impact as possible. However, the Institute also continued to recognize that the needs of its members always come first, and did not compromise on the quality of service offered. Overall, the Institute did reasonably well and for the first time since 20014/2015 managed to show a small but noteworthy surplus for the financial year. This is attributed to the hard work and commitment of the staff and conference teams, as well as volunteers among members of the Institute.

\section{Strategic Planning for the SAIMM}

The SAIMM is focusing on its strategic planning for the next 510 years, and started the process by holding a strategy session for the Technical Programme Committees. (TPCs) The TPCs have agreed on a mandate as well as six work streams which include digitalization, stakeholder engagement, publicity, KPI successes, conference delivery mechanisms, and data gathering and analysis. The SAIMM Office Bearers have held a number of facilitated sessions during which they spent some time developing a vison for the Institute, as well as a number of work streams that seek to support the vision, and focusing more on the overall future performance and outlook for the Institute. The work streams are still to be finalized.

\section{Financials}

Our financial performance is covered in detail in the Honorary Treasurer's report. In 2015 it was forecast that our Institute would operate under serious financial strain due to the economic downturn and deficits were predicted for three consecutive years. In the past year, however, the Institute managed to reach a turning point and recorded a surplus of R5 018 353. This was realized through the continuing of strict cost control measures, and more significantly through the revenue brought in by our conferences. In particularly, the Infacon conference held in Cape Town did exceedingly well and contributed considerably to the positive financials of the Institute. We are thankful to our dedicated conference team of both staff and volunteers who continue to work diligently in this regard. The remainder of the income was derived from contributions from Branches, sales of books, and Journal subscriptions. Revenue from advertising, on the other hand, continues to be down, which is a consequence of the challenges faced by the mining industry and indicates a potential change in terms of advertising needs and trends.

The investment started the financial year at R29 714155 and ended the year at R31 697 557. An amount of R2.5 million was drawn down from our AFC-managed investment portfolio. Part of this drawdown (R500 000) includes a pay-out from the Infacon funds that the SAIMM has held on behalf of Infacon since 2004 . The money was released on request to provide support for research being undertaken in the ferroalloy industry.

\section{Membership}

Our membership is drawn from more than 50 countries and currently stands at 5077 . About $90 \%$ of the membership continues to be drawn from the Southern African region, and almost half of the total membership is drawn from the younger professionals. More importantly, female membership is now standing at $20 \%$, which is a significant improvement from the $18 \%$ recorded in the $2016-2017$ term. The fact that the SAIMM manages to attract young professionals is a sure indication that the Institute is a dynamic organization that is going to be around for many more years to come. A few of our members continue to need support due to the unemployment situation arising from the industry downturn. Being the caring organization that we are, the SAIMM has deferred the payment of the membership fees at the request of those members. It is, however, noteworthy that some of the members that had requested deferment of membership subscription in the past have since found employment and settled their outstanding fees, and thus continue to receive the numerous benefits of being a SAIMM member.

\section{Publications}

The Institute continued to deliver on one of its key objectives, that of disseminating scientific and technical knowledge to the benefit of the minerals industries. Technical and scientific knowledge was shared through the Journal, which is published monthly and distributed to all members either electronically or 
through the post. There continues to be a significant drop in the demand for the hard copy, and it is hoped that this trend will continue so that the Institute can save on the cost of printing and postage. Significant highlights from the Publications Department include the following:

> There were eight themed issues of the Journal with papers for these publications being drawn from various conferences. This is a testament that our conferences not only attract high-quality speakers, but also high-quality papers and presentations that can be converted to Journal papers.

> The introduction of the Open Journal System (OJS) for managing and reviewing the papers submitted for publication to the SAIMM Journal. This is part of benchmarking the Institute against international standards and makes the submission and reviewing process much more efficient and easier for both the authors and the reviewers.

> Indexing of our Journal in the Directory of Open Access Journals (DOAJ). This is expected to benefit the Institute and its members through increased dissemination, and hence a wider audience for published papers and better visibility for the authors.

> Completion of a peer review of the Journal by the Committee on Scholarly Publishing in South Africa under the direction of the Academy of Science of South Africa (ASSAf), which concluded that our Journal should continue to be listed on the Department of Higher Education and Training (DHET) list of accredited journals.

> A year-on-year improvement of $10 \%$ in our Journal Impact Factor and a source normalized impact per paper (SNIP) factor of 0.8. This is a clear indication that our Journal is finding a wider readership with each passing year.

\section{Technical Conferencing}

The Mining and Metallurgy Technical Programme Committees (TPCs) successfully organised 19 events on a variety of topics that are relevant to the minerals industry. The delegate attendance increased slightly by 100, up from 3146 recorded for last year. Some of the successful events included both international and regional conferences such as AfriRock, which the delegates described as a world-class international event with excellent technical content and outstanding keynote speakers. The Infacon XV conference drew a large attendance ( 450 people from 32 countries) and was deemed by the delegates to be the best ferroalloy conference currently available, with the major benefits of providing delegates with an opportunity to meet technical leaders in the industry and discuss the latest trends. The Seventh International Platinum Conference was held in conjunction with the Advanced Metals Initiative (AMI) conference in Polokwane, allowing the delegates the opportunity to attend both conferences, and this is another successful initiative from the SAIMM.

Another conference worth noting is Digitalization in the Minerals Industry, which was held in June. The presentation topics highlighted the fact that digitalization is seen as a strategic imperative in the industry and there were many really great examples of tangible value-add. The conference is the first in a series of conferences, forums, and business breakfasts that the SAIMM will be hosting in collaboration with industry and other partners to assist the industry on its journey towards Mining 4.0.

The SAIMM has also been on a drive to hold major conferences in collaboration with our regional branches, and the 2017-2018 term saw the Uranium 2017 conference being held as part of this initiative. This conference was held in Swakopmund, Namibia on the outskirts of the Namib Desert and was well attended by both regional and overseas delegates. Other branches also held a number of events, with the Western Cape focusing on student-oriented events, Zimbabwe organizing an event that focused on building a robust economy in that country, and the Johannesburg Branch holding a number of successful presentations which included the annual Student Debate, organized for the first time jointly with the YPC. The annual Student Colloquium was also well attended by both local and regional universities, with students from regional universities such as the National University of Science and Technology in Namibia and the University of Zimbabwe giving the local students some serious competition.

A number of breakfast sessions were also held, chief among these being the bi-monthly breakfast talks hosted by the SANCOT Committee. Two other noteworthy sessions were the Mining Charter breakfast and the Women in Mining breakfast, which was held jointly with Women in Mining South Africa (WiMSA). The Mining Charter breakfast was the first breakfast forum organized by the SAIMM and was well attended, indicating that the ability of the Institute to tap into topical issues is an important consideration for its members. The Women in Mining breakfast was the first ever event run by the SAIMM that focuses on the challenges faced by women in the mining industry. This session was also well attended, generated positive feedback, and more events along this line such as a workshop and a conference are expected in the future.

Despite the continuing economic challenges faced by mining and mining-related companies, the SAIMM has continued to receive sponsorship support for most of our technical events, thereby enabling us to reduce the registration cost per delegate, which is of significant benefit to our members. The Institute is very grateful for this generous support.

\section{Collaboration through the Global Mineral Professionals Alliance (GMPA)}

In March 2018 the SAIMM, represented by Sam Moolla, the Office Manager, attended the annual meeting of the Global Mineral Professionals Alliance (GMPA) hosted by the CIM in Vancouver, Canada. The GMPA is a collaboration between leading professional minerals-related organizations around the world and comprises the Australasian Institute of Mining and Metallurgy (AusIMM), the Canadian Institute of Mining, Metallurgy and Petroleum (CIM), the Institute of Materials, Mining and Metallurgy (IOM3), the Southern African Institute of Mining and Metallurgy (SAIMM), the Society for Mining, Metallurgy and Exploration Inc. (SME), and the Instituto de Ingenieros de Minas del Peru (IIMP).

\section{GMPA members are required to:}

$>$ Work together to identify and deliver collaborative projects that are of mutual benefit 
> Share knowledge and resources regarding effective ways to support the professional development of institutal members

$>$ Be a partner of - or commit to joining - the OneMine global mining database.

The participation of the SAIMM in the GMPA ensures that members are able to enjoy reciprocal benefits from the other participating societies. It also enables the SAIMM to gain an understanding of how sister organizations in the minerals industry are operating, which helps benchmark the Institute's performance and activities for the benefit of our members.

\section{Collaboration with local professional associations}

The SAIMM maintained interaction with a number of local kindred professional associations affiliated to the minerals industry. This was done in several ways, including attending their annual general meetings and other annual functions, having reciprocal observer status at each other's council meetings, and in some cases by jointly organizing technical events. A typical example is the MineSafe Conference, which is organized in conjunction with . These associations include the:

> Geological Society of South Africa (GSSA)

> Association of Mine Managers of South Africa (AMMSA)

- Mine Metallurgical Managers Association (MMMA)

- Institute of Mine Surveyors of South Africa (IMSSA)

- Mine Ventilation Society of South Africa (MVSSA)

> South African Colliery Managers Association (SACMA)

> Southern African Coal Processing Society (SACPS)

> Fossil Fuel Foundation (FFF)

> South African Institution of Chemical Engineers (SAIChE)

> South African Institute of Electrical Engineers (SAIEE)

> South African Academy of Engineering (SAAE)

$>$ Women in Mining South Africa (WIMSA).

The SAIMM is also part of the South African Forum of Engineers (SAFE), a forum that provides a platform for voluntary associations (VAs) to speak with a common voice on matters that affect the engineering community. One of the pertinent issues being considered by the VAs which are part of SAFE is the ECSA court case. This case challenges the legitimacy of the ECSA Council appointed in 2016, and was brought to court in March 2017. Although the case is still ongoing the VAs, through SAFE, are also investigating other alternatives in order to solve this issue such that there is minimum adverse impact on both the VAs, their members, and ECSA.

The SAIMM has also initiated closer ties with the Minerals Council South Africa (formerly known as the Chamber of Mines), and two meetings were held with their executive members. The Chief Executive of the Council, Mr Roger Baxter, was the recipient of the SAIMM's most prestigious award, the Brigadier Stokes Memorial Award, in 2017. The relationship is expected to develop and grow in the coming year to the benefit of both parties.

\section{The Young Professionals Council (YPC)}

One of the most successful initiatives of the SAIMM is the Young Professionals Council. I was fortunate enough to be present at the initial establishment of the YPC in 2013. The growth and development of the YPC since its establishment has continued to surpass expectations.
The YPC replaced the previous Career and Guidance Committee, and its main aim is to focus on matters that affect the young members ( 35 years and younger) of the Institute. Some of the successful initiatives include the establishment of an e-magazine known as 'Youth in Mining and Metallurgy', the mentorship programme, and the graduate employment database. All of these are making an impact on the lives and careers of the student and young professional members of the Institute. After focusing all its energy on harnessing and establishing the brand through local activities since its founding, the YPC started branching out into regional branches in the 2017-2018 term. The YPC was successful in taking significant steps to engage young professionals in Zimbabwe and Namibia through student chapters. The section on the YPC in this report gives further details of activities undertaken in the past year. The significant success of these activities indeed highlights that the SAIMM managed to identify a gap and subsequently provide support to the challenges faced by our younger members.

\section{The Committee for Diversity and Inclusion in the Minerals Industry}

The SAIMM established a new initiative in the 2017-2018 term through the committee for Diversity and Inclusion in the Minerals Industry (DIMI). The committee will seek to advance diversity (gender, ethnicity, religion, and other diversifying factors) and inclusion in the industry through initiatives and activities that address the professional needs and aspirations of persons actively pursuing a career in the minerals industry. The committee will serve to bring awareness to the industry on the importance of valuing the contributions brought by all diverse individuals. The committee aims to achieve the above professionally through sharing of knowledge and learning via activities such as presentation of technical papers at conferences, seminars, and running of workshops. The committee will also be looking at topics that draw men into the discussions so as to create a more open dialogue. The committee is made up of both males and females, young and experienced members, who are all passionate about seeing positive changes in the minerals industry.

\section{The SAIMM annual banquet}

We held the annual banquet early in February and it attracted 340 attendees from 22 companies embracing academia, consulting firms, operations, and kindred organizations. We were privileged to also have companies from our regional branches sponsoring and attending the event. It is interesting to note that although the mining industry is still recovering from the economic downturn, there remains a significant interest in attending the banquet for the social and networking opportunities that it affords the attendees. This has indeed become a social highlight for the Institute and this year we were honored to be entertained by the young and vibrant Parktown Boys Brass Band. The SAIMM is pleased to have been able to afford the youngsters the opportunity to entertain our guests, and the boys were well received. And as in the past, the banquet also provided an opportunity to introduce and recognize new Fellows and as part of the Incentive Programme, recognize contributions made by our members who went the extra mile in supporting key activities of the Institute. 


\section{Staff}

Following on the number of changes to the SAIMM staff in 2017, there was a period of learning over the financial year but the staff have come through it stronger, with a greater ability to take on challenges and work as a team. During the 2017-2018 term Gugu Charlie gave birth to a beautiful baby girl on 27 June. Yolanda Ndimande (previously Ramokgadi) rejoined the SAIMM on 1 of March as Conference Coordinator. She left the SAIMM in 2016 due to a relocation, and we are excited to have her back. Tshepiso Lethlaku (previously Letsogo) attended a professional switchboard, reception, and frontline skills course, and has become the vibrant and confident voice of the SAIMM.

In total, the SAIMM staff of 15 have an accumulated 129 years of service, which is quite an achievement. Anna Panana (28 years of service) Aphathia Sello (19 years), Julie Malgas (18 years), and Nazli Mamdoo (18 years) are testament to the SAIMM being a family and not just a business.

\section{Conclusion}

The activities of the SAIMM mentioned in this report clearly indicate a dynamic and forward-looking Institute that is attuned to its members. The Institute continues to adapt to the changing mining landscape while keeping its eyes always on the needs and interests of its members. In a couple of years the SAIMM will turn 125 years old. However, the Institute remains young, vibrant, active, and strong, with the source of its strength remaining in its members. Members who have and continue to show an interest in the Institute's activities, thus forcing the Institute to always reassess and re-evaluate its offerings so as to remain relevant. Members who selflessly participate at all levels, and leaders of the Institute who dedicate enormous effort and time to ensuring that the values and mission of the Institute are kept alive. I have no doubt that we will leave a legacy to our children who, together with their descendants, will see another 125 years of the Institute in the future.

\subsection{Awards and Adjudication Committees}

Awards and Adjudication Committee-Mining

M.H. Rogers, Chairperson

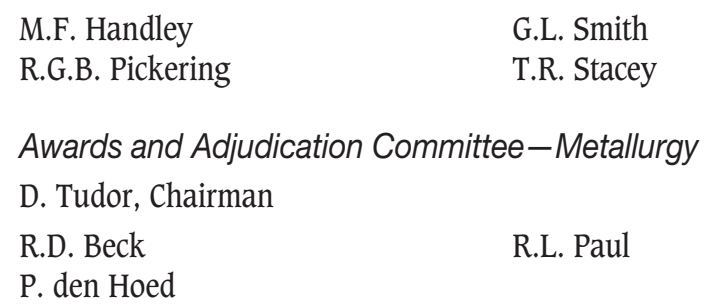

\section{Honorary Life Fellows}

Honorary Life Fellowship is awarded by Council to Corporate Members of the Institute who have rendered outstanding service to the industry or to the Institute over a considerable period. Council has conferred Honorary Life Fellowship on the following persons:

Pre-

$\begin{array}{lll}1923 & \text { A. Aiken } & \text { S.H. Pearce } \\ & \text { A.F. Crosse } & \text { J.P. Williams } \\ & \text { J. Littleton } & \\ 1923 & \text { J. Moir } & \end{array}$

1930 H.A. White

1931 P. Cazalet

A. Whitby

1932 J.R. Thurlow

1934 Wm. Cullen

W.R. Feldtmann

E.H. Johnson

1938 G. Melvill

S. Newton

1941 J. Henderson

1943 Sir R.N. Kotzé

1946 J. van N. Door

C.J. Gray

J. Gray

J.V. Muller

J. Orr

1951 W.W. Mein

1953 P.E. Hall

1954 C. Biccard Jeppe

1955 P.N. Lategan

1958 R.A.H. Flugge-de-Smidt

1960 G. Hildick-Smith A.J. Walton
A.J. Orenstein
F. Wartenweiler

H.J. van Eck

1961 C.S. McLean

1966 F.G. Hill

1970 H.E. Cross

R.C.J. Goode

1974 R.J. Adamson

W. Bleloch

H. Britten

1975 M. Barcza

J. de V. Lambrechts

1976 D.G. Maxwell*

1978 J.K.E. Douglas

D.D. Howat

1979 J.P. Hugo

1980 Hon. S.P. Botha

Hon. P.G.J. Koornhof

A. Louw

1982 M.G. Atmore

1983 C.S. MacPhail

1985 P.R. Jochens

D.G. Malan

1986 D.G. Krige

1987 A.N. Brown

1988 J.D. Austin

R.P. King

R.S.G. Stokes

S.J. Truscott

G.A. Watermeyer

J.A. Woodburn

B. St. J. van der Riet

F. Meyer

D.M. Jamieson

C.J. Irving

J.F. Reid

J.T. McIntyre

A.R.O. Williams

V.C. Robinson

P.W.J. van Rensburg

R.P. Plewman

R.E. Robinson*

M.D.G. Salamon

G.Y. Nisbet

D.A. Viljoen

1989 P.A. von Wielligh

1990 S. Budavari

L.W.P. van den Bosch

1991 H. Wagner

1992 J. Lurie

1993 No award

1994 B.C. Alberts

1995 R.D. Beck

P.R. Janisch

1996 R.J. Dippenaar

J.S. Freer*

1997 J.A. Cruise

1998 D.A.J. Ross-Watt 


$\begin{array}{ll}1999 & \text { No award } \\ 2000 & \text { N.A. Barcza } \\ & \text { R.P. Mohring* } \\ 2001 & \text { M.H. Rogers } \\ 2002 & \text { L.A. Cramer } \\ & \text { C.T. O'Connor } \\ 2003 & \text { A.A.B. Douglas } \\ 2004 & \text { No award } \\ 2005 & \text { F.A. Camisani-Calzolari } \\ 2006 & \text { T.R. Stacey } \\ 2007 & \text { No award } \\ 2008 & \text { E.U.H. Sachse } \\ 2009 & \text { I. Walton } \\ 2010 & \text { R.T. Jones } \\ 2011 & \text { No award } \\ 2012 & \text { No award } \\ 2013 & \text { No award } \\ 2014 & \text { G.V.R. Landman } \\ & \text { A.S. Macfarlane } \\ 2015 & \text { O.K.H. Steffen* } \\ 2016 & \text { R.C.A. Minnitt } \\ & \text { J.L. Porter } \\ 2017 & \text { D. Tudor } \\ 2018 & \text { M. Woodhall } \\ \text { *Deceased }\end{array}$

J.R. Dixon

D.J. van Niekerk

R.F. Sandenbergh

J.H. Selby

P.J. Knottenbelt

R.G.B. Pickering

M.F. Handley

S.J. Ramokgopa

G.L. Smith

\section{Brigadier Stokes Memorial Award}

The Brigadier Stokes Memorial Award, which takes the form of a platinum medal, is awarded to an individual for the very highest achievement in the South African mining and metallurgical industry, and is not necessarily based on technical expertise.

The Award was established in 1980, and the previous recipients were as follows:

$\begin{array}{ll}1980 & \text { H.F. Oppenheimer } \\ 1981 & \text { W. Bleloch } \\ 1982 & \text { F.G. Hill } \\ 1983 & \text { A.W. Whillier (posthumously) } \\ 1984 & \text { D.G. Krige } \\ 1985 & \text { R.E. Robinson } \\ 1986 & \text { M.D.G. Salamon } \\ 1987 & \text { T.F. Muller } \\ 1988 & \text { W.J. (Wim) de Villiers } \\ 1989 & \text { R.A. Plumbridge } \\ 1990 & \text { W.G. Boustred } \\ 1991 & \text { P. du P. Kruger } \\ 1992 & \text { E. Pavitt } \\ 1993 & \text { D.A. Pretorius } \\ 1994 & \text { H. Wagner } \\ 1995 & \text { O.K.H. Steffen } \\ 1996 & \text { B.E. Hersov } \\ 1997 & \text { D.W. Horsfall (posthumously) } \\ 1998 & \text { B.P. Gilbertson } \\ 1999 & \text { L. Boyd } \\ 2000 & \text { A.H. Mokken } \\ 2001 & \text { T.L. Gibbs } \\ 2002 & \text { J. Ogilvie Thompson } \\ 2003 & \text { P.V. Cox } \\ 2004 & \text { H.J. Smith } \\ 2005 & \text { P. Motsepe } \\ 2006 & \text { G.T. van Rooyen } \\ & \end{array}$

$\begin{array}{ll}2007 & \text { D.H. Laubscher } \\ 2008 & \text { T.R. Stacey } \\ 2009 & \text { C.J. Fauconnier } \\ 2010 & \text { C.T. O'Connor } \\ 2011 & \text { B.C. Alberts } \\ 2012 & \text { R.P. Mohring } \\ 2013 & \text { H.R. Phillips } \\ 2014 & \text { R.M. Godsell } \\ 2015 & \text { S.A. Nkosi } \\ 2016 & \text { M.A. Hermanus } \\ 2017 & \text { R.A. Baxter } \\ 2018 & \text { M.S. Teke }\end{array}$

This year the award is made to Michael Solomon Teke for his outstanding contribution to the industry over many years.

\section{SAIMM 50 Year Club}

The Institute established the 50 Year Club in 1989 to recognize the faithful and loyal support of its senior members with 50 years' unbroken membership. They become members of the club on the 50th anniversary of their joining the Institute. Their names are published each year in the Annual Report and they are presented with a gold lapel badge on a suitable occasion. There are no fees, and the only obligation of members is to wear their lapel badges with pride and affection at all meetings of the Institute. The present members of the club are as follows:

\begin{tabular}{|c|c|c|}
\hline \multicolumn{3}{|l|}{ Year to } \\
\hline June & \multicolumn{2}{|l|}{ Member } \\
\hline 1924 & \multicolumn{2}{|l|}{ E.C. Polkinghorne* } \\
\hline 1926 & \multicolumn{2}{|l|}{ R.M. Martin* } \\
\hline 1927 & \multicolumn{2}{|l|}{ W. Allen* } \\
\hline 1930 & \multicolumn{2}{|c|}{ E.T. Dunstan* (posthumously) } \\
\hline 1931 & \multicolumn{2}{|l|}{ F. Bowdler* } \\
\hline 1932 & \multicolumn{2}{|l|}{ J.E. Laschinger* } \\
\hline \multirow[t]{4}{*}{1933} & F.D. Cartwright* & E.R.C. O'Connor* \\
\hline & C.H. Coxon* & B.M. Roberts* \\
\hline & J. Levin* & A.A. von Maltitz* \\
\hline & D.D. McWilliam* & T. Waterman* \\
\hline \multirow[t]{4}{*}{1934} & A.C.M. Cornish-Bowden* & J.W.V. Mortleman* \\
\hline & H.E. Cross* & K. Rood* \\
\hline & E.F. Laschinger* & A. Siff* \\
\hline & E. Margo & O. Weiss* \\
\hline 1935 & O.B. Swallow* & \\
\hline \multirow[t]{6}{*}{1936} & O. Deane* & A.H. Mokken* \\
\hline & T.L. Gibbs* & H.L. Munro* \\
\hline & R.C.J. Goode* & R.M.F. Seawright* \\
\hline & F.G. Hill ${ }^{*}$ & A.C. Pigott* \\
\hline & D.M. Jamieson* & J.S. van Zij ${ }^{*}$ \\
\hline & D.J. Rogers* & L. Walter* \\
\hline \multirow[t]{3}{*}{1937} & W. Bleloch* & J.J. Klein* \\
\hline & L.A. Bushell* & C.D. Storrar \\
\hline & K.W. Findlay* & \\
\hline \multirow[t]{5}{*}{1938} & V.C. Barnes* & C.A. McKechnie* \\
\hline & E.T.S. Brown* & J.A. Nixon \\
\hline & R.S. Cooke* & E. Popplewell* \\
\hline & J.K.E. Douglas & C.G. Sowry* \\
\hline & A.L.A. Forder* & E.W. Thiel* \\
\hline \multirow[t]{3}{*}{1939} & G. Armstrong-Smith* & R.S. Pearson* \\
\hline & D.E.R. Ayres* & D.C.J. Squirrell ${ }^{*}$ \\
\hline & E.H.D. Carman & R.F.J. Teichmann* \\
\hline
\end{tabular}




\begin{tabular}{|c|c|}
\hline & W.G.H. Jackson* \\
\hline & T.A. Newman \\
\hline 1940 & L.D.C. Bok ${ }^{*}$ \\
\hline & A.W.L. Brereton* \\
\hline 1941 & A.H.H. Davison* \\
\hline & D.J. Forder \\
\hline & A.R.C. Fowler* \\
\hline & H.F.W. Ketelbey* \\
\hline & J.D. McNamara* \\
\hline & T.F. Muller* \\
\hline 1942 & R.E. Burnton* \\
\hline & R.C. Espley-Jones* \\
\hline & N.M. Hayne* \\
\hline & R.T. Naudé* \\
\hline 1943 & D.J. Molony* \\
\hline & J.D. McMorran* \\
\hline 1944 & A.F. Dick \\
\hline & R.B. MacGillivray* \\
\hline & L.J. Prince* \\
\hline & J.F. Reid* \\
\hline 1945 & J.L. Curtis* \\
\hline & E.T. Pinkney* \\
\hline 1946 & W.I. Spence \\
\hline 1947 & G.H. Grange \\
\hline & W.B. Howe \\
\hline & J. Marr-Levin \\
\hline & C.J. Parr* \\
\hline 1948 & D.F. Foster \\
\hline & M.H. Grusd* \\
\hline & P.A. Laxen* \\
\hline & G.Y. Nisbet \\
\hline 1949 & G.P. Bennett* \\
\hline & J.F. Curtis* \\
\hline & O. Davel \\
\hline 1950 & D.F. Grieve \\
\hline & B.E. Hersov \\
\hline & D.G. Maxwell* \\
\hline 1951 & D.G. Krige* \\
\hline & B.H.L. Leach \\
\hline & M.J. Martinson \\
\hline & W.D. Ortlepp* \\
\hline 1952 & A.N. Brown \\
\hline & M.J. Deats \\
\hline & W. Lurie* \\
\hline & N. Martincevic \\
\hline 1953 & B.G. Fordyce \\
\hline & G. Langton* \\
\hline & A.A. Sealey \\
\hline 1954 & R.C. Bertram \\
\hline 1955 & R.A.O. Chelius* \\
\hline & S.P. Ellis \\
\hline & C.T. Fenton \\
\hline 1956 & G.A. Brown \\
\hline & D.R. Chelius \\
\hline & M.F. Dawson* \\
\hline & L.M. Falcon \\
\hline 1957 & K. Babich \\
\hline & J.J. Blom \\
\hline & R. Campbell \\
\hline 1958 & J.F. Dear* \\
\hline & R.H. Swan \\
\hline
\end{tabular}

I.S. van Eyssen*
S.J. Venning*
G.D. Gettliffe*
G.G. Stanley*
D. de V. Oxford*
E. Pavitt
A.C. Petersen*
E.R. Rudolph*
P.W.J. van Rensburg*

O.L. Papendorf*

V.O. Steed

J.E. van Leeuwen*

W.C. Walmsley*

R.P. Plewman*

V.M. Reinecke*

A.S. Swartz

A.H. Taute*

P.B. Weehuizen*

K.E. Steele*

J.D. Pollard

V.C. Robinson*

A.N. Shand*

G.R. Still

J. Pope*

N.A. Stacey

J.A. Tyser

J.P. Hugo

D.A. Immelman

R.P. Plasket*

V.C. Ward

N.C. Pope

W.T. Ruhmer

T. Zadkin*

\section{E.P. Mortimer}

D.J. Murphy

H.J. Stucke*

R.G. Williams

G.D. Tainton

J. Uys*

N. Zolezzi

R.B.W. Wiggill

G.R. Parker

W.B. Parker

M.A. Madeyski*

D. Rankin

G.C. Thompson

A.M. Edwards

R.C. More O'Ferrall

N.C. Officer

B.S. Tatterson

P.J. van der Walt

\begin{tabular}{|c|c|c|}
\hline 1959 & $\begin{array}{l}\text { H.E.K Allen } \\
\text { D.C. Brink } \\
\text { G.D. Louw }\end{array}$ & $\begin{array}{l}\text { H.A.G. Slater } \\
\text { G.T. Van Rooyen }\end{array}$ \\
\hline \multirow[t]{5}{*}{1960} & R. Hemp & C.T. Shaw* \\
\hline & G. Joynt & L.W.P. van den Bosch* \\
\hline & B. Moore & H. von Rahden \\
\hline & R.E. Robinson* & M. Wishart \\
\hline & C. Roper & \\
\hline \multirow[t]{5}{*}{1961} & W.B. Evans & G.S. Lee \\
\hline & R.A. Featherstone & B.J. Love \\
\hline & I.R.H. Forrest & P.J. Muller \\
\hline & J.S. Freer* & G.J.C. Young \\
\hline & B.W. Holtshousen & W.J.G. Young \\
\hline \multirow[t]{2}{*}{1962} & S.I. Du Preez & E. Schmid \\
\hline & P.J. Heystek & \\
\hline \multirow[t]{5}{*}{1963} & L. Anderson & J.N. Gallie \\
\hline & H.K.R. Cahnbley & J.J. Geldenhuys \\
\hline & G.C. Clatworthy & T.J. Kotze \\
\hline & R.E.F. Cowley & A.H. Munro \\
\hline & J.A.J. De Cuyper & A.G. Netto \\
\hline \multirow[t]{2}{*}{1964} & J. Douglas & A.W. John \\
\hline & K. Imre & A. Simon \\
\hline \multirow[t]{9}{*}{1965} & P. Andersson & W. Mitchell \\
\hline & J.A. Cruise & D.I. Ossin \\
\hline & F.S.A. De Frey & M.H. Rogers \\
\hline & F.M.G. Egerton & E.H.J. Stoyell \\
\hline & F. Fenwick & R.S. Traviss* \\
\hline & M.R. Fuller-Good & J.W. Walls \\
\hline & P.G. Gaylard & I.C. Watson \\
\hline & J.P. Hoffman* & J.C.M. Wethmar \\
\hline & J.P. Loo & \\
\hline \multirow[t]{5}{*}{1966} & D.A. Arnold & N.F. Peverett \\
\hline & C. Fauconnier & J.C. Simms \\
\hline & D.R. Fleming & P.J.C. Smith \\
\hline & E. Fletcher & O.K.H. Steffen* \\
\hline & P.G.P. Mrkusic & D.J. van Niekerk \\
\hline \multirow[t]{6}{*}{1967} & H.G. Albertyn & H.E. Lombard \\
\hline & N.A. Barcza & M.C.W. Morris \\
\hline & A.G.C. Merson & W.A. Nairn \\
\hline & P.J. Cook & A.D. Ochse \\
\hline & C.V.B. Cunningham & M.v.R. Steyn \\
\hline & N.C. Joughin & P.S. Wentworth \\
\hline
\end{tabular}

* Deceased since becoming members of the Club

\section{The Danie Krige Memorial Award}

Following discussions at Office Bearers and Council during 2013 it was agreed to honour the memory and contribution to the minerals industry made by the late Professor Danie Krige.

It was agreed, amongst other activities, to make an annual award of a Danie Krige medal for a qualifying geostatistics paper published in the SAIMM Journal of the previous year.

There is no award this year.

\section{Gold and Silver Medals}

Papers published in the Journal from March 2017 to February 2018 by members of the Institute were considered for medals.

\section{Gold Medals}

Gold medals are awarded for papers that are of a world-class standard, and judged to be publications that will become key 
references in their mining or metallurgical field in the future.

There was no award this year.

\section{Silver Medals}

Silver medals are awarded for papers that make a major contribution to the professions of mining and metallurgy and to the prestige of the Institute.

Silver Medals were awarded to:

E.L. Forner, S.J. Archer, V.E. Coetzee, K. Soldenhoff, and J. Quinn, for their paper published in the February 2018 issue of the Journal entitled: 'Uranium recovery from high-chloride sulphate leach solutions: A cost trade-off study of using treated water $v s$. saline water as make-up water' .

As non-members, V.E. Coetzee, K. Soldenhoff, and J. Quinn will receive certificates of merit.

D. Roberts for his paper published in the July 2017 issue of the Journal entitled: 'Calibration of a numerical model for boreand-fill mining'.

\section{Student Prizes}

Prizes were awarded to the following students and were presented at faculty prizegiving ceremonies held at the respective universities.

The prize winners were as follows:

\section{University of the Witwatersrand}

$\begin{array}{ll}\text { Mining Engineering } & \text { S.T. Motha } \\ \text { Metallurgical Engineering } & \text { M. Dlamini }\end{array}$

\section{University of Pretoria}

Mining Engineering

Metallurgical Engineering

\section{J.-P. Labuschagne J. Wicks}

\section{University of Johannesburg}

Extractive Metallurgy

R. Moanakoena

\section{University of Cape Town}

Mineral Processing

To be announced

University of Stellenbosch

Mineral Processing

To be announced

\section{Cape Peninsula University of Technology}

\section{Chemical Engineering}

To be announced

The prizes for the universities of Cape Town and Stellenbosch and the Cape Peninsula University of Technology will be awarded at the Western Cape Branch Annual General Meeting on 3 September 2018.

In addition, the Western Cape Branch also awards two Outotec Postgraduate Scholarships for students conducting research in the area of sustainable mineral processing.

There was no award this year.

\section{SAIMM 5 Star Incentive Programme}

The SAIMM 5 Star Incentive Programme was introduced in 2015 to thank members who contribute to the growing membership of the SAIMM and to provide additional benefits to Fellows and Members of the SAIMM.
The Top 5 proposers are:

D. Muma

G. Dabula

S. Nhleko

M. Erwee

W. Joughin

The Top 5 referees of papers published in the Journal are:

M. Dworzanowski

M. Erwee

M. Handley

N. McGeorge

S. Rupprecht.

The author who has submitted and published the most number of papers in the Journal is:

J. Bunt.

\section{Top Advertiser in the Journal}

The award for the Most Supportive Advertiser in the Journal is to be made annually by the SAIMM and it is the Institute's way of recognizing the continued and loyal support of those companies that advertise in our Journal. The award is made not only on the strength of the amount of money spent by an advertiser, but also on factors like general cooperation, meeting of deadlines, and the timely settling of accounts. Our advertisers make a major contribution to the Institute's ability to provide our members and associates with a quality Journal.

The Most Supportive Advertiser for 2017/18, and for the second year running, is Elbroc Mining Products.

\subsection{SAIMM Scholarship Trust Fund}

J.R. Dixon, Chairman
A.S. Macfarlane
M.H. Rogers
T.M. Mmola
W.H. van Niekerk

Nothing to report this year.

\subsection{Complaints Committee}

R.C.D. Phillis (Chairperson)
M. Dworzanowski
A.J. McDonald
A.M. Garbers-Craig

Nothing to report this year.

\subsection{Banquet Committee}
S. Ndlovu
Z. Botha
A.S. Macfarlane
V.G. Duke

M.I. Mthenjane

The banquet was held on Saturday, 17 February 2018 in the Ballroom at the Sandton Convention Centre.

There were 340 guests in total. There were three VIP tables, which included the SAIMM Office Bearers and Presidents of kindred organizations. Twenty-three companies ranging from academia institutions, consultants, operations, and kindred organizations sponsored the event.

The presentation of certificates to Fellows who were elected in the preceding year was instituted in 2016. This year it was once again well received, and the Fellows were pleased to be awarded their certificates at the event. In addition, it was agreed that the top five members in the different categories of 
the Five Star Incentive Programme and their partners would also be invited to the banquet at no cost. This opportunity was also received positively by these members, who provide essential support to the SAIMM.

The Parktown Boys Brass Band provided the entertainment. The youngsters rose to the occasion and their talent was self-evident from the accolades of the guests.

The evening flowed well, and the entertainment, presentations, good food and wine, and networking were complimented on by a number of the guests.

As always, the SAIMM extends its appreciation to the companies who sponsored the event and we look forward to seeing them all at the next banquet.

\section{Technical Meetings}

\section{Portfolio Holders: R.T. Jones and C. Musingwini}

Although the mining and metallurgy TPCs are managed separately committees, the focus this year has been on working more closely and integrating mining and metallurgy in our industry programmes. Therefore for the first time this report is combined.

Thanks to the members of the respective committees for their contributions to a full programme this year.

\subsection{Technical Programme Committee-Mining}

G.R. Lane, Chairperson

$\begin{array}{ll}\text { R. Armstrong } & \text { D. Muma } \\ \text { L. Dimbungu } & \text { C. Musingwini } \\ \text { N. Dirande } & \text { N.M. Namate } \\ \text { N. Diyambas } & \text { A. S. Nhleko } \\ \text { W.C. Joughin } & \text { J.L. Porter } \\ \text { D. Limpitlaw } & \text { S. Pule } \\ \text { J.A. Luckmann } & \text { S. Rungan } \\ \text { A.S. Macfarlane } & \text { S. Rupprecht } \\ \text { A. Mainza } & \text { C.B. Smith } \\ \text { S. Maleba } & \text { M.H. Solomon } \\ \text { H. Marsden } & \text { A.L. Swart } \\ \text { S. Matutu } & \text { M. Tlala } \\ \text { C.W. Mienie } & \text { C. van Wyk } \\ \text { R.C.A. Minnitt } & \text { R.C.W. Webber-Youngman } \\ \text { T.M. Mmola } & \text { M. Woodhall } \\ \text { B. Morena } & \end{array}$

\subsection{Technical Programme Committee-Metallurgy}

Z. Botha, Chairperson

I. Geldenhuys, Co Chairperson

$\begin{array}{ll}\text { R.D. Beck } & \text { A. Mulaba-Bafubiandi } \\ \text { N.G.C. Blackham } & \text { D. Muma } \\ \text { T. Claassens } & \text { N. Namate } \\ \text { P. den Hoed } & \text { N. Naude } \\ \text { N. Dirande } & \text { S. Ndlovu } \\ \text { N. Diyambas } & \text { A.S. Nhleko } \\ \text { M. Dworzanowski } & \text { N. Segapela } \\ \text { D. Groot } & \text { J.H. Selby } \\ \text { R.T. Jones } & \text { H. Simonsen } \\ \text { A. Mainza } & \text { K.C. Sole } \\ \text { E. Matinde } & \text { J.D. Steenkamp } \\ \text { S. Matutu } & \text { A.L. Swart } \\ \text { C. Mienie } & \text { M.M. Valenta } \\ \text { T.M. Mmola } & \text { P. van Staden } \\ \text { M. Motuku } & \text { C. van Wyk }\end{array}$

R.D. Beck

N.G.C. Blackham

N. Diyambas

D. Groot

R.T. Jones

M. Motuku
The TPC recognizes the changing needs of our members and other industry stakeholders. Therefore the TPC held a strategy workshop session in November 2017 and agreed a TPC vision and mandate for 2018. Great participation from committee members resulted in a mandate that was signed off by the SAIMM Council.

The final approved mandate for 2018 is as follows.

$>$ Innovate

> Facilitate the dissemination of relevant knowledge and experience to the benefit of all SAIMM members and stakeholders

> Facilitate independent fact-based discussion of topics of relevance to SAIMM members and stakeholders

> Foster collaboration in the interests of all our members and global stakeholders

> Encourage SAIMM members and our stakeholders to propose topics of interest for conferences or other events, and provide an independent platform for these events to be held

> Coordinate and support the events programme to ensure overall financial sustainability of the SAIMM.

The strategy session also identified six priority strategic projects required to deliver on this TPC mandate. Each workstream has a project leader and workgroup made up of TPC Committee members and any other volunteers as may be required.

Digital strategy - leverage innovative digital solutions to assist with the efficient delivery of the TPC mandate Innovate, Collaborate, Facilitate, and Coordinate.

G. Lane (Workgroup Lead)

C. Jardine, Secretariat

N. Wernecke, Secretariat

A. Mulaba-Bafubiandi

R.T. Jones

W. Joughin

M. Woodhall / J. Liebenberg

This workstream was completed in April 2018 and delivered the following:

1. Digital conferencing facilities for all SAIMM meetings using the latest Zoom technology - this allows remote members and Branches to join all meetings, with significant savings in travel costs, and also encourages participation by remote members.

2. Social media strategy for marketing of all conferences

3. Digital portal for refereeing technical papers. The SAIMM Journal system was evaluated and found to meet all requirements, and this will be rolled out as soon as it is fully implemented for the Journal

4. Digital conference streaming globally - leveraging of the Zoom technology to stream conferences to the audience both locally and internationally. This is not intended to replace the physical conference but to reach a broader audience. This will be rolled out during 2018 on a trial basis.

5. Conferencing app - an app for conferences enabling delegates to see the programme, presenter biographies, presentation downloads, and communications. This was piloted at the recent Digitilization in Mining conference and proved very successful. This will now be rolled out as a standard for conferences, and at a later point as a 
SAIMM communication app for members.

Knowledge portal - the Zoom technology allows for a knowledge portal of past conference presentations. The technology is therefore available and will be implemented in 2019.

Innovative conference delivery mechanisms - investigate new approaches to delivering conferences that addresses current member and industry needs.

Rudrajit Mitra (Workgroup Leader)
G.R. Lane
M. Nasiri
J.A. Luckmann
M. Wertz

B. Morena

This workstream was completed in April 2018 and delivered the following.

1. Investigation of industry needs - delegates on operations cannot afford the time to attend multi-day conferences. The SAIMM should take conferences to the operations with digital streaming to the delegates, and organize mini-forums and breakfasts on relevant topics. There is a requirement for continuing professional development that does require the traditional conferences.

2. A programme of mini-forums and business breakfasts on relevant industry topics leading to a large multi-day conference.
3. Digital live streaming of conferences to a local and international audience with a different pricing model using Zoom video conferencing technology.

4. Webinars of relevant content and topics from the conferences using Zoom video conferencing technology.

Engage Stakeholders - identify all SAIMM stakeholders and engage with them to understand their needs from the SAIMM

S. Ndlovu (Workgroup Lead)

Office Bearers

Past Presidents

S. Moolla

This workstream is still in progress.

Communicate to Stakeholders - engage with all identified stakeholders and communicate the SAIMM value proposition to them.

R.T. Jones (Workgroup Lead)

This workstream is still in progress.

TPCs and conference performance measures - identify the key performance measures for the TPCs and conferences.

A.S. Macfarlane (Workgroup Lead)

Z. Botha

This workstream was completed in June 2018 and identified

Schedule of Mining/Metallurgy Technical Conferences, 2017/2018

\begin{tabular}{|c|c|c|c|}
\hline Type of Event & Date & Title & Convenor \\
\hline Conference & 10-11 July 2017 & Water in Mining & M. Valenta \\
\hline Conference & 25-26 July 2017 & YPC: Entrepreneurship in Mining & G. Dabula \\
\hline Conference & 3-4 August 2017 & Building a robust minerals industry - ZIM & S. Matutu \\
\hline Conference & 7-8 August 2017 & Rapid underground mine \& civil access 2017 & M. MacNab \\
\hline Workshop & 15-16 August 2017 & SAMREC/SAMVAL Advanced Workshop & K. Lomberg \\
\hline Breakfast & 22 August 2017 & Mining Charter Breakfast & M. Tlala \\
\hline Conference & $\begin{array}{l}30 \text { August to } \\
1 \text { September } 2017\end{array}$ & Mine Safe 2017 & T. van der Berg \\
\hline Conference & 11-13 September 2017 & Uranium 2017 & D. Groot \\
\hline Workshop & 19-20 September 2017 & GMSG Workshop & D. Vogt \\
\hline Conference & 2-6 October 2017 & AfriRock 2017 & W. Joughin \\
\hline Conference & 17-20 October 2017 & AMI Precious Metals 2017 & G. Pattrick \\
\hline Conference & 18-20 October 2017 & Platinum 2017 & G. Smith \\
\hline Colloquium & 25 October 2017 & Student Colloquium 2017 & N. Segapela \\
\hline Conference & 25-28 February 2018 & Infacon 2018 & R.T. Jones \\
\hline Breakfast & 13 February 2018 & Women in Mining Breakfast & Z. Botha \\
\hline Breakfast & 15 February 2018 & SANCOT Breakfast & R. Tluczek \\
\hline Conference & 12-14 March 2018 & SOMP Regional Congress & R. Mitra \\
\hline Workshop & 23-26 April 2018 & Multiple Point Statistics School & R. Minnitt \\
\hline Conference & 6-7 June 2018 & Digitalization in Mining 2018 & A. Macfarlane \\
\hline Conference & $11-14$ June 2018 & Diamonds 2018 & T. Mrshall \\
\hline Breakfast & 21 June 2018 & SANCOT Breakfast 2018 & R. Tluczek \\
\hline Workshop & 20 June 2018 & GMSG Workshop & J.J. Verhaeghe \\
\hline
\end{tabular}


the quantifiable key performance metrics for the TPCs and conferences.

Historical Data Analysis - understand the past performance of conferences to understand if any key insights can be generated.

The workgroup lead withdrew due to the work commitments and no replacement could be found due to the workload of committee members. The format of the actual TPC meetings has also been changed to remove all administration functions. This allows the committee members to focus on learnings from past conferences, assist organizing committees where required with challenges for upcoming conferences, and be more strategic in terms of a longer-term conference programme. The agenda programme has now been extended to a two-year window with the intention of extending to three years so that there is adequate time to liaise and coordinate for possible international conferences.

The past 12 months has seen an upturn in conference attendance compared to the previous year, which is a sign of an improvement in the industry. Unfortunately, we still see the majority of delegates coming from consulting companies, vendors, OEMs, and academic institutions. To attract more delegates from the mining companies we will be organizing mini-forums and business breakfasts in central locations, and also live streaming of conferences. We also recognize that there is significant value in our conference programme in terms of continuing professional development, and therefore we are now approaching the mining companies to form a strategic relationship for a full year's conference programme.

We appeal to our corporate members and company affiliates to please support the TPC conference programme as the quality programme can only be offered through the support of members and industry.

Please engage with any of the TPC Committee members if you would like to host a sponsored business breakfast, a miniforum on a specific topic, or to share leading-edge work being done in the industry.

A total of 19 conferences were held in the last financial year, totalling 40 full conference days. With the focus on integration of the full mining value stream, eleven of these conferences combined mining and metallurgy.

\section{CONFERENCE BY EVENT TYPE}

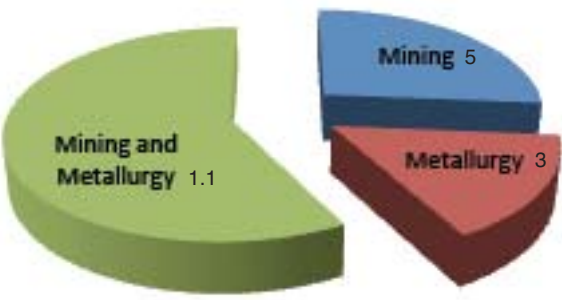

Delegate numbers increased from 3146 to 3246 for the last financial year.

\section{ATTENDEE BREAKDOWN}

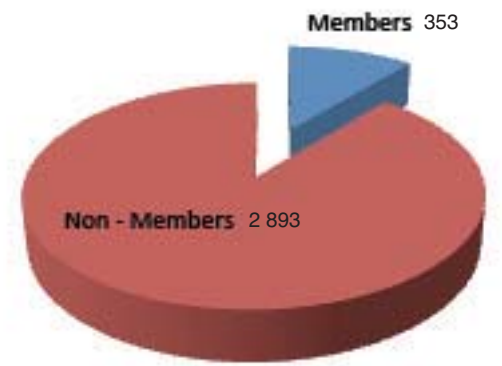

The majority of delegates (77\%) were from South Africa, and $10 \%$ were from Europe.

\section{ATTENDANCE BY CONTINENT}

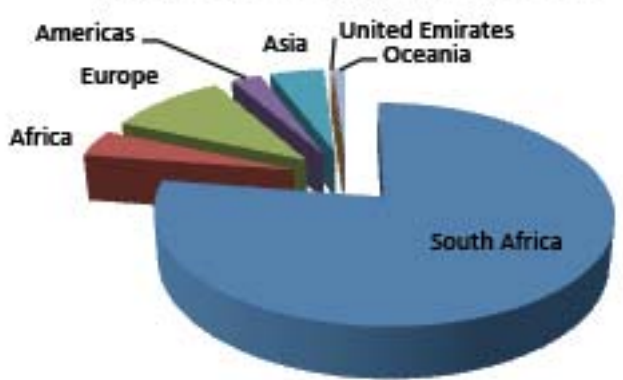

It is extremely encouraging to see the diverse spread of countries that support our conferences.

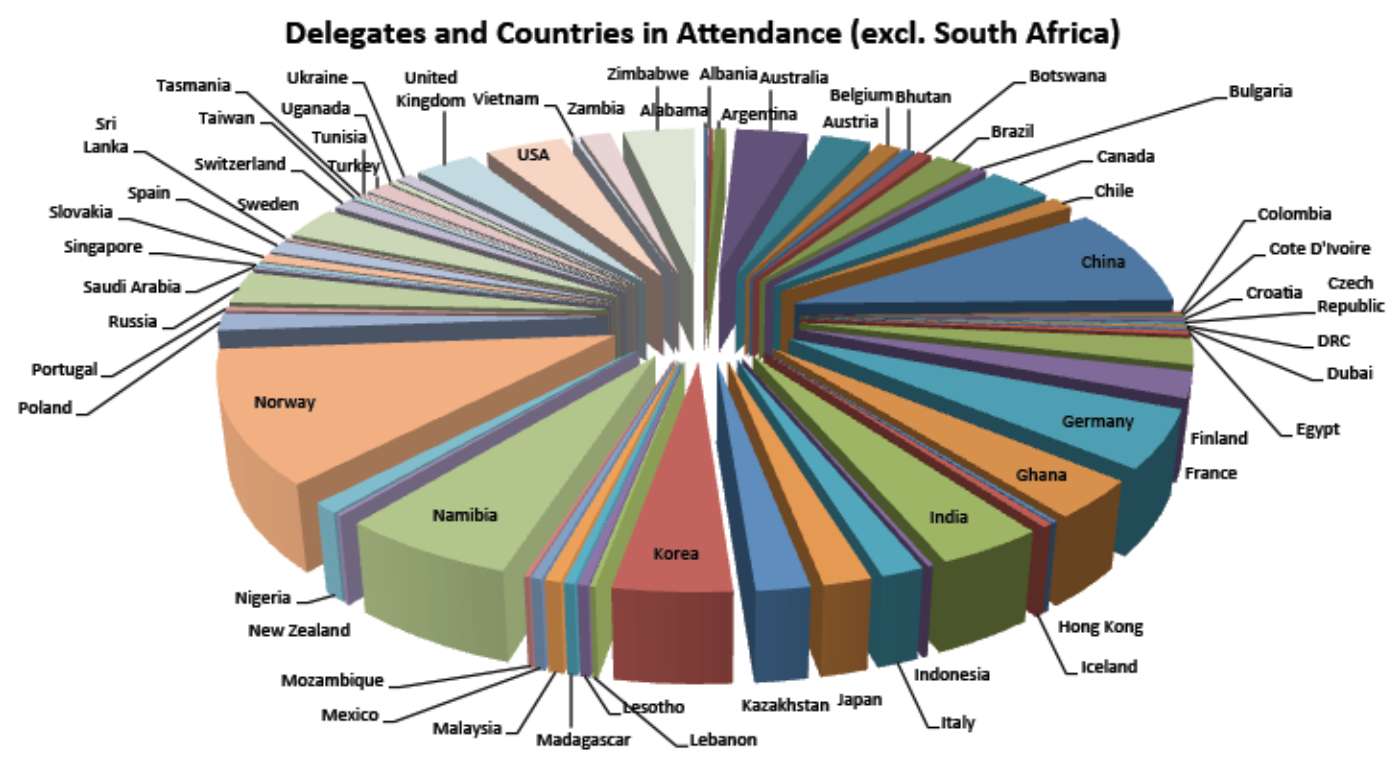


The conference programme for the last financial year is shown in the accompanying table.

The TPCs fulfils a critical role in terms of providing a platform for innovation, facilitation, coordination, and collaboration as regards industry knowledge. The delivery of this also ensures the financial sustainability of the SAIMM and we greatly appreciate industry's willingness to sponsor events to the total of R4.48 million during the period.

Thank you to all our members, company affiliates, and other stakeholders for their participation and support during this last financial year.

\subsection{South African National Committee on Tunnelling (SANCOT)}

H.J. (Ron) Tluczek, Chairperson

C. Viljoen, Vice Chairperson

L. Nene, Chairperson: Young Members Group

G. Davis

D. Roos

P.H. Ferreira

T.R. Stacey

I. Jacobs

F.B. Stevens

J. Jansen

E.J. Walls

K. Jordaan

M. Wainstein

M. Lebitsa

A. Widlake

J.L. Porter

H. Wolfgang

S. Rhodes

International Tunnelling Association (ITA) News

The International Tunnelling and Underground Space Association (ITA) held its 44th General Assembly along with the 2018 World Tunnel Congress (WTC) in Dubai (UAE) from 22 to 25 April 2018. Seventy-four member nations participated in the conference and New Zealand became the 75th member nation.

South African representatives participate in three of the ITA Working Groups. Ron Tluczek is Vice-Animateur of WG 2 (Research), Chris Viljoen participates in WG 12 (Sprayed Concrete Use), and Monica Walnstein in Working Group 21 (Life Cycle Asset Management). Unfortunately, due to work pressure, none of the South African representatives were able to attend this year's Congress.

Two reports were published in the previous year from two ITA Working Groups, namely:

WG 5: Guidelines for the Provision of Refuge Chambers in Tunnels Under Construction - V2

WG 5: Guidelines for Good Working Practice in High Pressure Compressed Air - V2

These documents are available free of charge on the ITA website, and comments are invited.

The next annual meetings of the ITA General Assembly will be held at the following venues:

Naples, Italy, from 2 to 9 May, 2019, during the ITA-AITES WTC 2019 Tunnels and Underground Cities: Engineering and Innovation meet Archaeology, Architecture and Art.

Kuala Lumpur, Malaysia, from 15 to 21 May, 2020, during the ITA-AITES WTC 2020 Innovation and Sustainable Urban Connectivity.

Copenhagen, Denmark, from 14 to 20 May, 2021.

A moment of silence was held during the opening speech at the 44th General Assembly to honour ITA members who had passed away, notably:
Franz Pacher, who was one of the chief developers of the New Austrian Tunnelling Method (NATM)

Don Deere, the inventor of the rock mass assessment tool, the RQD - Rock Mass Designation

Z.T. (Richard) Bieniawski, who invented the world-famous Rock Mass Rating (RMR).

\section{SANCOT NewS}

One of the main focus areas for SANCOT is to promote interaction and closer communication between personnel and companies in the mining and civil industries, and to create a platform where expertise and experience gained in underground excavation can be shared.

To this end, an initiative was implemented in September 2017 where a breakfast talk is given prior to the regular SANCOT committee meetings. The talk is given at the offices of GIBB Engineering and Architecture, who also sponsor the breakfast. The breakfast talks are held every two months and anyone is welcome to attend. The topics have included:

> Tunnelling trends in South Africa - past, present and future

> The use of micro-tunnelling with a lake tap for a proposed dam outlet

> Horizontal raiseboring technology and its advantages in mechanized mining

> The use and benefits of utility tunnelling

Future talks will include topics such as:

> Geotechnical considerations in recent Scandinavian tunnelling projects

> Cement injection for mining and tunnelling

The talks have been well received and are attended by consultants, contractors, academics, students, managers, financiers, and sales personnel. At the last talk, a group of PDI women who have started their own businesses attended to see where they may be able to assist.

With the prospect of several major tunnelling projects on the horizon, the active SANCOT membership is increasing. Major projects that are either current or imminent are:

(a) The Lesotho Highlands Water Scheme, Phase II, which will incorporate the Polihali dam, the extension of the Muela hydroelectric complex, and the construction of $38 \mathrm{~km}$ of water transfer tunnel. This scheme is current and will augment the water supply to the Gauteng area.

(b) The uMkhomazi Water Transfer Scheme, which will incorporate the Smithfield dam and $34 \mathrm{~km}$ of water transfer tunnel. This scheme is imminent and will augment the water supply to the area under the jurisdiction of the Umgeni Water Board.

(c) The Overvaal tunnel, a new double-bore railway tunnel. This scheme is imminent and will be constructed to alleviate the bottleneck on the Richards Bay Coal Line due the existing single-track tunnel.

(d) Remedial works to the Mohale tunnel which links the Mohale and Katse reservoirs. This scheme is current and will entail reinstating the grouted annulus behind the tunnel segmental lining.

Three Working Groups are active within SANCOT, namely: WG 14: Vertical Tunnelling 


\section{WG 21: Life Cycle Asset Management}

The third Working Group is looking at hosting the ITA World Tunnel Congress in Cape Town, South Africa in 2022. This is a result of numerous enquiries that Ron Tluczek received at recent ITA World Tunnel Congresses, and there would appear to be a lot of international support to hold a WTC in Africa, and specifically in South Africa.

Currently, SANCOT is preparing to host a seminar on microtunnelling on 4 September. This conference will highlight the advantages of installing utilities in underground works and will be aimed at the numerous municipalities, water utilities, and mines that have underground utilities. Due to rapid urbanization, it is often no longer possible to install utilities in conventional 'cut and cover' trenches. A common call on the international tunnelling stage at present is 'Surface Problems Underground Solutions'.

\section{Publications}

\section{Portfolio Holder: A.S. Macfarlane}

D. Tudor, Chairperson

$\begin{array}{ll}\text { R.D. Beck } & \text { H. Lodewijks } \\ \text { P. den Hoed } & \text { C. Musingwini } \\ \text { M. Dworzanowski } & \text { S. Ndlovu } \\ \text { B. Genc } & \text { J.H. Potgieter } \\ \text { M.F. Handley } & \text { N. Rampersad } \\ \text { R.T. Jones } & \text { T.R. Stacey } \\ \text { W.C. Joughin } & \text { M.R. Tlala }\end{array}$

J.A. Luckmann

\subsection{Journal}

The breakdown of papers published during the year and previous years is as follows:

$\begin{array}{ccccc}\text { Year } & \text { Mining } & \text { Metallurgy } & \text { Other } & \text { Total } \\ 2016 & 59 & 76 & 2 & 137 \\ 2017 & 87 & 41 & 7 & 135 \\ 2018 & 64 & 72 & 5 & 141\end{array}$

Of the 141 papers published in $2017 / 18,58$ were from outside South Africa. The rejection rate of papers received was $31 \%$. There were seven themed editions of the Journal during the year.

Advertising revenue for the year was some $2 \%$ below last year's figure. The continuing decline in advertising revenue is a direct reflection of the challenges that the mining industry as a whole faces.

A gradual reduction of the monthly print run from 2325 to 1775 copies was achieved during the year, which was some way short of the target of 1500 copies. This was mainly due to the fact that only $33 \%$ of the membership has replied to the survey questionnaire to establish the number of members that no longer require a hard copy of the Journal and would prefer to receive an electronic copy.

In March 2018 we received the final report on the peer review of the Journal. The peer review process is run under the auspices of the Academy of Science of South Africa (ASSAf) and is intended to improve the Journal's quality, visibility, and impact. The peer review panel's consensus was that the Journal should continue to be listed on the Department of Higher Education and Training (DHET) list of accredited journals. A number of suggestions for improvements were made, which are under consideration by the Publications Committee.

The potential publication of a number of books covering a range of topics remains in the early stages of investigation.

The award for the Most Supportive Advertiser in the Journal for the year 2017/18 is to be made to Elbroc.

During the course of the year we gradually migrated the reviewing of papers that are submitted to the Journal to the Open Journal System (OJS), which can be viewed at https://saimmjournal.co.za Authors and reviewers are required to register on the OJS and this has enabled a substantially paper-free process for managing the progress of a paper from submission to publication. Refining of the system to suit all the needs of the Journal continues.

We are indebted to our members who undertake the onerous task of refereeing papers. The meaningful feedback that the referees provide to the authors of papers has contributed enormously to maintaining the standard of the content of the Journal.

The publications team of Kelly Matthee and Zuliakha Malgas, with occasional input from Dawn van der Walt and Naomi Wernecke, has continued its good work in producing the Journal.

\section{Regional Development}

\section{Key Performance Areas}

To promote the interests of members based in different regions, the SAIMM:

- Supports the establishment and maintenance of branches to satisfy the local needs of its members for professional association and the exchange of technical information

- Co-operates with other member societies of AS\&TS and with associations and interest groups that have close ties with operating mines and metallurgical plants by holding joint technical meetings and collaborating in the field of publication.

\subsection{SAIMM Branches}

\subsubsection{Botswana}

\section{L.E. Dimbungu, Chairperson}

No report was available at the time of going to print.

\subsubsection{DRC Branch}

S. Maleba, Chairperson

D. Sambwa, Vice-Chairperson

G. Kalama, Vice-Chairperson

D. Tshibanda, Secretary
P. Kalala
C. Byakoukou

R. Kazembe

No report was available at the time of going to print.
4.1.3 Johannesburg Branch
J.A. Luckmann, Chairperson
H. Jantzen, Vice Chairperson
D. Jensen, Secretary
J. Clarke
D. Porter 


$\begin{array}{ll}\text { D. De Wit } & \text { D. Powell } \\ \text { G. Dellas } & \text { N. Rampersad } \\ \text { A. Dougall } & \text { J. Ruddy } \\ \text { C. Heili } & \text { S. Rupprecht } \\ \text { R. Heins } & \text { G. Stripp } \\ \text { A. Kinghorn } & \text { M. Tlala } \\ \text { M. Mostert } & \text { B. Van Houten } \\ \text { S. Nhleko } & \end{array}$

I am pleased to report on the activities of the SAIMM Johannesburg Branch for the period 1 July 2017 to 30 June 2018.

The Branch's main activity was the organizing of technical presentations on a monthly basis, excluding the DecemberJanuary holidays. These techical presentations were generally held on the third Thursday of each month, at the premises of WorleyParsons at Melrose Arch. During the period under review, the Branch Committee succeeded in securing eight technical presentations, plus one students' debate which was held in August 2017.

The Branch greatly values students' involvement in its presentations, and notes that many of those attending have chosen to become Student Members of the Institute, with a good conversion ratio to Associate Membership after graduation. Student attendance was understandably constrained over the current session by external events impacting on transport, and is of course subject to academic commitments.

The challenging economic situation continues to put pressure on sponsorship received, while the Branch's success in encouraging student participation may be expected to impact on the costs associated with the technical presentations and associated networking events. The Committee has therefore endeavoured to continue to control costs, with the most significant measure being the change in approach to sponsorship undertaken by Branch Secretary Danie Jensen.

\section{Events}

The Committee was able to secure twelve sponsors to support Branch events in the 2017-2018 session. The sponsorships received and accounted for ensured that the entire programme of technical presentations held between July 2017 and June 2018 was fully funded.

The 2017-2018 session commenced on 20 July 2017 with a technical presentation entitled 'Petra Diamonds latest diamond processing technologies' presented by Deon Swanepoel, Executive of Petra Diamonds (Pty) Ltd and fully sponsored by the company.

The Annual Student Debate, entitled 'The Future of Artisanal and Small Scale Mining in the South African Mining Industry', followed on 24 August 2017. The students were clearly well prepared, which resulted in a lively and interesting debate.

On 19 October, Richard Ferreira from the IMS addressed the Branch on the subject of 'Unlocking value in comminution and separation processes'. IMS South Africa provided full sponsorship for this event.

The November technical presentation, held on 16 November 2017, was entitled 'Anatomy of a modern diamond plant in the mid-tier sector', presented by Derek Lahee from Consulmet South Africa and kindly sponsored in full by Consulmet SA.

We started the New Year on 15 February 2018 with a presentation entitled 'Is the South African coal mining industry ready for women? by Moses Ramokhothoane, General Manager of New Denmark Colliery and sponsored by the New Denmark Colliery South Africa.

Following this, on 15 March 2018, Clive Stewart, Business Development Manager of Traxys, spoke on the subject of 'The business of Commodity Trader - getting the result of your efforts to market'. Traxys (Pty) Ltd provided full sponsorship on this occasion.

On 19 April 2018 the Branch held a technical presentation entitled 'The new paradigm of abundance versus the old paradigm of scarcity and how mining might assist'. This thought-provoking topic was examined by Professor Anthony Turton and sponsored by the Johannesburg Branch.

The May technical presentation, held on 17 May 2018, considered the topical issue of 'Converting artisanal mining to small-scale mining in Africa', with Professor Steven Rupprecht from the University of Johannesburg reviewing developments on the continent. The Johannesburg Branch was again the sponsor of the presentation.

The Branch also provided sponsorship for the concluding presentation of the 2017-2018 session, entitled 'Exact art and subtle science of metal recovery in a DC arc furnace', held at WorleyParsons on 21 June 2018 and presented by Isabel Geldenhuys from Mintek.

\section{Finance}

The Committee succeeded in achieving its objective of fully funding the planned twelve-month programme of Branch activities, with a modest surplus of R19 887 reported for the year ending 30 June 2018.

\section{$A G M$}

The Johannesburg Branch AGM was held on 21 June 2018, immediately after the final Branch meeting of the 2017-2018 session.

The outgoing Chairperson welcomed Branch members and guests, including SAIMM President Selo Ndlovu and President Elect Alastair Macfarlane.

After confirmation of a valid quorum, sixteen members of the Branch who had been nominated to serve on the Committee for 2018-2019 were duly elected by a show of hands. John Luckman, Hein Jantzen, and Danie Jensen were re-elected to serve as Branch Chairperson, Vice Chairperson, and Secretary, respectively. Kelly Clarke was welcomed as a new member of the Committee for 2018-2019, while the Chairperson bade farewell to Jeremy Clarke, Andre Dougall, Russell Heins, Maurice Mostert, and Mpho Tlala, thanking them for their invaluable contribution to the outgoing Committee. He also expressed his appreciation of the role of the SAIMM Secretariat, including Sam Moolla, Kea Shumba, Prudence Ntumeleng, and Naomi Wernecke, for their co-ordination and administration of Branch events.

The AGM concluded with welcome words of encouragement from the current SAIMM President and the President Elect, who both confirmed the importance of young professionals' involvement in the Institute's future development.

\subsubsection{Namibian Branch}

N.M. Namate, Chairperson

B. Sililo

F. Uahengo (YPC Coordinator) 
Referees of papers submitted during 2017/2018

\begin{tabular}{|c|c|c|c|}
\hline Abbasy, Farzaan & Geldenhuys, Isabel & Maree, Jannie & Schmitz, Peter \\
\hline Aken, Mark & Genc, Bekir & Marriott, John & Schoeman, Janine \\
\hline Aldrich, Chris & Gentle, Frank & Marshall, Tania & Sellers, Ewan \\
\hline Andrews, Anthony & Gericke, Mariekie & Marx, Wynand & Sheridan, Craig \\
\hline Auret, Lidia & Gerritsen, Terry & Matinde, Elias & Shoesmith, David \\
\hline Austin, Mark & Gibson, William & McGarr, Art & Sibanda, Vusumuzi \\
\hline Badenhorst, Heinrich & Goldbach, Olaf & McGeorge, Norman & Simonsen, Henry \\
\hline Bals, Alex & Goode, John & Miller, Graeme & Simser, Brad \\
\hline Barcza, Nicholas & Grenon ,Martin & Minnitt, Richard & Siyasiya, Charles \\
\hline Barker, Ian & Grobler, Hendrik & Mitra, Rudra & Smit, Abre \\
\hline Bartlett, Hugh & Guest, Alan & Moller, Heinrich & Smith, Gordon \\
\hline Basson, Frans & Gunther, Peter & Morris, Dave & Sole, Kathy \\
\hline Beck, Richard & Gwynn, Xander & Motsa, Bongani & Spearing, Sam \\
\hline Behrang, Farshadi & Hadjigeorgiou, John & Moult, Steve & Spottiswoode, Steve \\
\hline Bepswa, Paul & Hall, Ian & Mousset-Jones, Pierre & Stacey, Thomas \\
\hline Beukes, Paul & Handley, Matthew & Mpunzi, Philani & Stenzel, Gerhard \\
\hline Bilgin, Nuh & Harker, William & Muaka, Joseph & Stewart, Paul \\
\hline Birtles, Andy & Harley, Michael & Muller, Jacques & Strauss, Kobus \\
\hline Blackham, Norman & Hattingh, Christo & Mutemeri, Nellie & Stripp, Graham \\
\hline Blinderman, Michael & Hattingh, Teresa & Naik, Sandip & Surridge, Tony \\
\hline Bluhm, Steven & Hay, Kevin & Napier, John & Sweet, Jenni \\
\hline Botin, Jose & Heugh, David & Nasiri, Mehdi & Terbrugge, Peter \\
\hline Bryson, Mike & Hiskey, Brent & Ndlovu, Selo & Theron, Kobus \\
\hline Burnett, Mark & Horsch, Hanna & Neale, John & Thomson, Andrew \\
\hline Canbulat, Ismet & Houman, Jaco & Nehring, Micah & Tluczek, Ron \\
\hline Carstens, Riaan & Howell, Graham & Nel, Jacques & Tudor, David \\
\hline Chatterjee, Snehamoy & Human, Louie & Nell, Johan & Tulu Ihsan, Berk \\
\hline Chown, Lesley & Hundermark, Rodney & Ngwato, Tara & Turton, Anthony \\
\hline Claassen, Marius & James, John & Njowa, Godknows & Uludag, Erhan \\
\hline Clark, Isobel & Johnson, Hilton & North, Brian & Uludag, Sezer \\
\hline Conradie, Phil & Joughin, William & O'Connor, Donald & van Aswegen, Gerrie \\
\hline Cornish, Lesley & Kalala, Johnny & O'Keefe, Christian & van der Linde, Gerhard \\
\hline Coulson, Nancy & Kapageridis, Ioannis & Ooosthuizen, Shaan & van Der Merwe, Josias \\
\hline Cowen, Dennis & Kauchali, Shehzaad & Osanloo, Morteza & van der Merwe, Nielen \\
\hline Craddock, Mark & Kennedy, Mark William & Oxtoby, Oliver & van Der Riet, Mark \\
\hline Cresswell, Mark & Killick, Andrew & Pariche, Morteza & van Der Vyver, Mientjie \\
\hline Crundwell, Frank & King, Matt & Patel, Bilal & van Dyk, Johan \\
\hline Cunningham, Claude & Knights, Peter & Peake, Andrew & van Hout, Gert \\
\hline De Graaf, Phil & Kotze, Hanlie & Phakathi, Sizwe & van Niekerk, Dirk \\
\hline De Jager, Kobus & Krassnokutski, Alexei & Phillips, Huw & van Rooy, Louis \\
\hline De Korte, Johan & Kruger, Buks & Pickering, Rod & van Schoor, Jan \\
\hline Deglon, David & Kruger, Leon & Pienaar, Marine & van Schoor, Michael \\
\hline Degraaf, Wolter & Kucukkaragoz, Cevat & Pinheiro, Henrique & van Staden, Petrus \\
\hline Dempsey, Paul & Kumral, Mustafa & Pistorius, Chris & van Zyl, PG \\
\hline Den Hoed, Paul & Lane, Gary & Pistorius, Pieter & Vanderlingen, Elma \\
\hline Di Giovinazzo, Michael & Leach, Tony & Plint, Neville & Velasquez, Raul \\
\hline Dimitrakopoulos, Roussos & Legodi, Christopher & Potgieter, Herman & Vervoort, Andre \\
\hline Dixon, Roger & Leshomo, Joyce & Power, David & Vietti, Andrew \\
\hline Dougherty, Heather & Lewis, Martin & Priest, Graham & Vogt, Declan \\
\hline Dreisinger, David & Limpitlaw, Daniel & Prins, Chris & Von Glehn, Frank \\
\hline Dunn, Michael & Lindsay, Colin & Prout, Barry & Vreugdenburg, Kobus \\
\hline Dworzanowski, Marek & Linzer, Lindsay & Radcliffe, Peter & Vusumuzi, Sibanda \\
\hline Engelbrecht, Andre & Lloyd, Philip & Ram, Rahul & Wagner, Nicola \\
\hline Erasmus, Lourens & Lodewijks, Henk & Ravary, Benjamin & Wakefield, Tim \\
\hline Eric, Rauf & Lomberg ,Ken & Redman, Kelly & Watson, Ingrid \\
\hline Erwee, Markus & Lorig, Loren & Reynolds, Quinn & Wells, John \\
\hline Esterhuizen, Essie & Loveday, Brian & Richards, Jill & Wertz, Marcin \\
\hline Falcon, Rosemary & Luckmann, John & Riesgo, Pedro & West, Richard \\
\hline Farmer, Iain & Luckos, Adam & Rivoirard, Jacques & Whittle, David \\
\hline Farshadi, Behrang & Lynch, Richard & Roberts, Dave & Whittle, Jeff \\
\hline Ferreira, Pete & Mackenzie, James & Roger, Paul & Whyte, Rod \\
\hline Fouché, Marnus & Madani, Nasser & Roode, Carel & Yahorava ,Olga \\
\hline Fourie, Henk & Mainza, Aubrey & Rorke, Tony & Yahyaei, Mohsen \\
\hline Freeman, Robert & Majozi, Thokozani & Ross, Victor & Zindi, Luke \\
\hline Garbers-Craig, Andrie & Malan, Francois & Rupprecht, Steven & Zungu, Lindiwe \\
\hline Gaylard, Jeremy & Malovichko, Dmitriy & Sandenbergh, Roelf & \\
\hline
\end{tabular}


The job market for mining-related professions remains under severe pressure. Major mines continue with care and maintenance or contract mining activities. Others have suspended operations completely. However, conditions are improving as there are a number of small mines entering production. The suspended operations at the major mines are on their way to being resuscitated and global commodity prices are improving.

Generally, the period has been slow, with not many members participating in Branch activities. Activities are largely voluntary and based on individual personal cost, which discourages participation. The Branch continues to observe that work pressure on potential members gives them little time attend to SAIMM affairs.

\section{Membership Recruitment}

The Branch Chair visited a number of mines in early March 2018 to raise awareness of the SAIMM and its activities. The tour took in Langer Heinrich, Husab, and Areva. Enthusiasm for membership still exists although actual registration is low. Discussions were held with a number of senior members in the industry to explain the need to support the Branch.

\section{Major Events in and around Namibia}

\section{Mining Expo}

The Branch participation at the Mine Expo in Windhoek on 25 and 26 April, 2018 was a success, with reasonable attention and interest being shown by professionals, some of which may translate into membership. However, the occasion was not as high flying as it could have been as the Branch participated under the auspices of NUST at their Chamber of Mines complimentary premises. The Branch's own budget would allow for the booking of an independent stand to conduct its own recruitment campaigns, and this should be the objective in future.

\section{Visit to University of Namibia Engineering Campus}

The Branch visited the UNAM José Eduardo Dos Santos Campus to give its first promotional presentation in the country. The aim of the visit was to promote the YPC and SAIMM among the students and staff. The presentation took place on 8 May 2018 and was attended by over 30 personnel and students. In addition to the presentation at the UNAM Campus, a stakeholders' dinner was held in Otjiwarongo in order to network with B2Gold (Otjikoto gold mine) and Gekko (Okorusu graphite mine) staff.

The presentation started with an introduction to the SAIMM, which was followed by the YPC promotional presentation by Ms Uahengo, who engaged the young professionals and the students regarding how they can add value to the professions of mining and metallurgy through the YPC. The students, most of whom were in their final year, showed interest in being part of the Institute and some embraced the invitation to become office bearers. This will be followed up in their second semester (mid-July), as the presentation took place close to examination time. Students who attended the presentation also communicated with other students who could not attend, and they too expressed their interest in becoming members of the YPC.

Three more presentations are planned for the central, south and coastal regions of Namibia (Otjiwarongo, Rosh Pinah, and
Windhoek) before the end of year.

\section{Financial}

The financial report from the Uranium Conference hosted in September 2017 is still awaited.

\section{General}

During his visit to Tanzania in June on other duties, the Branch Chair promoted the SAIMM to staff at the Mining and Chemical Engineering Department at the University of Dar es Salaam. The presentation was well received. Unfortunately, no application forms were carried on this trip, but potential members were encouraged to apply online.
4.1.5 Northern Cape
W.J. Mans, Chairperson
I. Lute, Vice Chairperson
F. Nieuwenhuys, Secretary
N. Buthelezi, Treasurer
E. Tanyane
J. Stoffels
H. Thomoli

\section{Strategy}

Increase membership numbers

> Marketing

> Facebook page

$>$ Internet

> Local newspapers

$>$ Posters

> Magazine articles

Events and networking visits

> Technical knowledge sharing

> Socializing

> Fun events

Corporate buy-in event

> Understanding technical difficulty

- Get specialist involvement

> More involvement by sponsors

> Technical Involvement

> One strategy event - market trends

> Specialist presenter

other events

$>$ AGM (August)

> Student event (January)

$>$ YPC (June)

> Evening event (November)

- Site visit (March)

Women in industry event (high tea) (February)

$>$ Get to know

$>$ Sponsorship

CSR (Corporate social responsibility event (July)

$>$ Tax rebate

> Presentation to scholars about the Industry

> Each Committee member to take different location 
> Take along bursary brochures - Introduction of industry and upliftment

\section{Membership Recruitment Activities and Proposals}

i. Defined the strategy of the Northern Cape Branch and submit to Council

ii. Define current status of Northern Cape Branch (how many members, cash flow, sponsorships, etc.)

iii. Distribute the Constitution of SAIMM for branches

iv. SAIMM Northern Cape membership list and distribution group

v. Reconciliation required on all outstanding actions from previous branch minutes - outstanding items needs to be closed-out

vi. SAIMM Northern Cape Branch KPIs, calendar, and induction pack distributed to members

a. The updated SAIMM Northern Cape Branch calendar for the year to be sent out for comments, committed dates. and responsible person

vii. Event planning discussion

a. Creating SAIMM Northern Cape event planning group

b. Use guidelines for event organizing as tool of assistance

c. Evening events (finger lunch with drinks and one presentation from $18 \mathrm{~h} 00$ to $19 \mathrm{~h} 30$ in various towns (Kathu, Hotazel, Lime Acres, Postmasburg, Springbok, Kimberley, etc.)

d. Create an event for GMs to build relationships between management and the SAIMM. Also include the Mine Managers Association

e. Need to thank all sponsors and presenters

f. Tshipi Borwa and Kolemela agreed to host site visits with presentations

g. More events will be held through videoconferencing, especially for remote branches like the Northern Cape

h. Need to get more buy-in from big contracting companies (Barlows, Komatsu, AEL, BME, Sasol Nitro, etc.) to sponsor and host events

viii. Create a SAIMM Northern Cape magazine editing group

a Create a SAIMM Northern Cape marketing group

b. What will we publish (6 months in advance)?

c. All the mines in the Northern Cape with diversity of resources

i. Mine-specific details

d. Need to supply background on mines and progress made on mining, metallurgy, and geological processes in the Northern Cape

e. Visit the SAIMM website and report in the monthly meeting on the latest listings

ix. Technical library not really utilized

x. Technical papers from mines not materializing

xi. Obtain involvement of HR Departments and assist in

Professional CV distribution

xii. Find out about memorabilia (jackets etc.)

xiii.

xiv. Try to obtain a better venue than KCC. How do

Members get CPD points for other professional councils like ESCA, MMASA, MEMSA, GSSA, etc. by attending SAIMM events?

\section{Upcoming Events}

Year-end function: Hosted by the Chairman and Vice Chairman at the Chairman's house. A very pleasant evening and well attended.

Site visits: Unfortunately, no site visits materialized

Sponsored evening events:

a. Event with MineWare, 16 May. This was the first sponsored evening event for the Branch, and very good feedback was received

b. Advertisement for the second sponsored evening event to go out 18 July. Hoping for better attendance after the first event that really went down well

i. 12 requests for sponsorship for evening events were sent out but only two companies came back to finalize. The rest of the companies will be invited to the AGM, which is already sponsored by Assmang

c. AGM and presentations at the AGM

\section{Activities}

Request to use facilities at KCC for meetings - not granted by Kumba Iron Ore

Request to use facilities at Uitkoms for meetings - not granted by Assmang

AGM venue request to use facilities at Uitkomst for the AGM granted by Assmang - AGM sponsorship and venue confirmed

\section{Important events in and around the region}

A Mining Expo again took place in June at various venues in the province. The organizers were willing to give the SAIMM a stand in exchange for Branch support at their next event, probably in September. Promotional material and support will be required from the SAIMM secretariat.

\section{Financial}

The costs of the planned events will be fully covered but no income will be generated at this stage. The main focus is on creating awareness of the SAIMM and encouraging membership.

\section{Annual General Meeting}

The Annual General Meeting is being organized for 3 August 2018. Nomination forms for Council and notices of the AGM are in the process of being sent out.

\subsubsection{Pretoria Branch}

R.J. Mostert, Chairperson

G. Ngema, Secretary

W.W. de Graaf

N. Naude

Professor Roelf Mostert accepted the position of Branch Chair after the emigration of Mr Bredell.

In August, the Pretoria Branch hosted a very successful YPC Career and Leadership event. The outgoing SAIMM President and a number of eminent keynote speakers gave inspirational talks to an audience that included a good number of students.

Next-generation bainitic steel with remarkable properties was the central theme of a colloquiuim coordinated by the Pretoria Branch and hosted by the Department of Materials Science and Metallurgical Engineering at the University of 
Pretoria on 4 December 2017. Sir Harry Bhadeshia, a global leader in metallurgy and the Tata Steel Professor at Cambridge University, was the main speaker. About 50 metallurgists from all over South Africa participated in the discussions.

A two-day seminar was co-hosted by the Branch on 7 and 8 March. The title of the seminar was 'Iron ore: mineralogy, fines processing, pelletizing and sintering'. The central SAIMM office assisted with promotion of the event, and it was very well attended (59 attendees). The Dean of the Faculty of Engineering, Built Environment and Information Technology at the University of Pretoria, Professor Sunil Maharaj, presented the welcoming address. Over the two days, three leading international scholars in the field (Dr Liming Lu from Australia, Dr Joseph Poveromo from the USA, and Professor Leal Laurindo from Brazil), as well as four local researchers, shared their knowledge and experience in this important field.

A fruitful meeting was held between office bearers of the SAIMM (Professor Selo Ndlovu, Ms Sam Moolla, Ms Kea Shumba) and the Pretoria Branch leadership. One outcomes was that the current SAIMM President would present a talk to senior mining and metallurgical engineering students at the University of Pretoria as part of a drive to increase student membership. The talk was held and good feedback received. In another event, a previous SAIMM President, Professor Rodney Jones, presented a paper to metallurgical students from junior to senior levels.

\subsubsection{Western Cape Branch}

R.D. Beck, Chairperson

L. Bbosa, Vice Chairperson

E. Chaikinya, Treasurer

C. Pomario, Secretary

M. Winter, Finance

M. Becker

T. Ojumu

D. Deglon

J. Petersen

J.A. Cruise

C. Sweet

C. Dorfling

J. Sweet

A. Mainza

M. Solomon

A. Nesbitt

M. Tadie

\section{Geometallurgy Conference}

As reported last year, the Branch plans to hold a Western Cape minerals research showcase every two years. This will be the traditional focus on research and activities of the Western Cape tertiary institutions, UCT, Stellenbosch, and CPUT.

In the interim years a national/international conference will be held. This year the subject of geometallurgy has been selected. It is believed that the value of geometallurgy is not fully appreciated. Geometallurgy is a highly structured, integrated multidisciplinary collaborative approach for optimizing the value of an ore deposit. The ability to manipulate and handle large amounts of data makes for many opportunities in this area.

Five keynote addresses and 23 papers make for interesting presentations and show the many opportunities presented by this field of interest, along with a better understanding of the subject.

The conference includes an interactive workshop on ore-tometals optimization that demonstrates the application of geometallurgy.

\section{IMPC 2020}

Planning has continued for the 2020 International Mineral Processing Conference, which is a major event on the international calendar.

\section{Students' Evening}

The 2018 students' evening, which introduces students to the SAIMM and the mining industry, will be held in September at Stellenbosch.

\section{Thanks}

My thanks to all Branch Committee Members, and in particular Megan Becker and the Geomet Conference Committee for their work during the year.

\subsubsection{Zambian Branch}

D. Muma, Chairperson

C. Mwale, Vice Chairperson

W. Munalula, Treasurer
C. Ngulube
H. Zimba

There has been significant growth in membership at all levels in the past 18 months, and this trend is expected to continue.

\section{Recent Activities}

There were few activities in the 2017-2018 term, apart from the informal membership awareness campaigns that have resulted in a spectacular growth in membership. Planned activities for the Branch are shown in the accompanying table.

\section{Other Activities}

\section{Young Professionals Council (YPC)}

An awareness campaign on the objectives of the SAIMM YPC formally commenced in May 2018. It is gratifying that we have for the first time been able to secure the nominations of three vibrant young Zambian mining professionals to the SAIMM

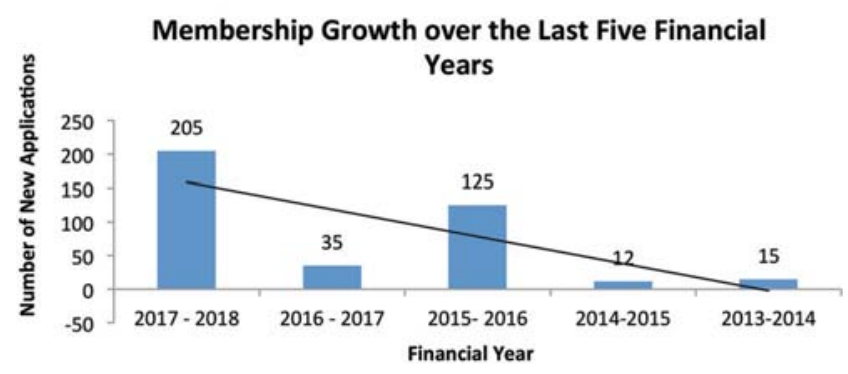

\begin{tabular}{|c|c|c|c|c|c|c|}
\hline \multicolumn{7}{|c|}{ Zambian Branch, membership growth by category } \\
\hline Year & Members & Fellows & Associates & Students & $\begin{array}{l}\text { Company } \\
\text { Affiliates }\end{array}$ & Total \\
\hline $2017-2018$ & 38 & 6 & 14 & 147 & 0 & 205 \\
\hline 2016-2017 & 11 & 0 & 2 & 22 & 0 & 35 \\
\hline 2015-2016 & 4 & 0 & 4 & 117 & 0 & 125 \\
\hline 2014-2015 & 7 & 0 & 4 & 1 & 0 & 12 \\
\hline 2013-2014 & 10 & 0 & 5 & 0 & 0 & 15 \\
\hline
\end{tabular}




\begin{tabular}{|c|c|c|c|}
\hline \multicolumn{4}{|c|}{ Planned Activity schedule } \\
\hline Date & Activity & Venue & Comment \\
\hline 25 May 2018 & Student Colloquium & $\begin{array}{l}\text { Copperbelt University } \\
\text { Kitwe }\end{array}$ & $\begin{array}{l}\text { Did not take place } \\
\text { due to cholera outbreak } \\
\text { resulting in changes in } \\
\text { school programme }\end{array}$ \\
\hline 5-7 June 2018 & $\begin{array}{l}\text { Copperbelt Mining } \\
\text { Technical Expo }\end{array}$ & Kitwe & $\begin{array}{l}\text { Did not take place, due } \\
\text { to inadequate } \\
\text { preparations }\end{array}$ \\
\hline 27 July 2018 & AGM & Chingola & Pending \\
\hline $\begin{array}{l}27 \text { September } \\
2018\end{array}$ & Technical Event & Mufulira Boating Club & Pending \\
\hline
\end{tabular}

YPC. The Branch YPC activities are expected to increase with the inclusion of the members from the local universities.

\section{Copper-Cobalt Conference}

The Branch's involvement in the preparation of the July 2018 Copper-Cobalt Conference, in collaboration with the conference organizing team at the Secretariat, has been very fruitful. This has resulted in an increased number of local participants compared to the last Copper-Cobalt Conference.

\subsubsection{Zimbabwean Branch}

Stanley Matutu, Chairperson

C. Sadomba, Vice Chairperson

O. Zvarevashe, Secretary

W. Kutekwatekwa, Treasurer

M. Hungwe, Youth Development

A. Chinhava, Youth Development

S. Gaihai $\quad$ S. Ndiyamba

Prof. Dzinomwa C. Tahwa

Prof. Ityokumbul

\section{Membership}

The membership drive targeted students from tertiary institutions offering mining and metallurgy programmes. The universities include the University of Zimbabwe, Midlands State University, Manicaland State University, and Zimbabwe School of Mines. Activities at each institution are facilitated by a student leadership comittee which coordinates all the SAIMM activities. The focus will be on offering more presentations from industry and senior members of the SAIMM to encourage active participation. Membership recruitment from the mining industry was subdued during the year due to the harsh eceonomic situation affecting the sector. The new political dispensation in Zimbabwe is expected to usher in new investments and promote growth in the mining sector, which will ultimately benefit the Branch.

An international conference on building a robust minerals sector in Zimbabwe was successfully held in July 2017. There was good attendance by around 200 delegates over the two days of the conference. The conference also offered an opportunity to recruit more members, particularly from students.

\section{Networking events}

The Youth Development Committee held a number of SAIMM membership presentations with students from tertiary institutions in Zimbabwe. The Branch hosted an international conference, 'Building a Robust Mineral Industry', in Harare in
July 2017. A number of local and regional presenters presented papers during the conference.

\section{Branch events}

The Branch had planned to visit the Mazoe mine dump retreatment project and the Cam and Motor mine gold project in Kadoma during the year. However, these events could not take place as the mines could not host the Branch due to the eceonomic difficuilties they are facing, and the projects they intended to showcase could not be commissioned in time. The hardships being experienced by mining companies in Zimbabwe continue to make it difficult to organize Branch events.

\section{International Conference on Innovation in Mining}

The Branch successfully hosted a two-day international conference on building a robust mineral industry in July 2017. The conference was held at Cresta Lodge, Msasa, in Harare. A total of 25 papers were presented by speakers from both international and local institutions. The attendance was very good, with delegates averaging 190 to 200 over the two days. A number of high-level dignitaries, including the Zimbabwe Minister of Mines and his deputy, the President of the Zimbabwe Chamber of Mines, and the SAIMM President, attended the conference. The conference was generously supported by various international and local mining companies and equipment suppliers.

The delegates requested the Branch to host another international conference in 2018. This is planned for November 2018 , and will take place held over three days, with a site visit to a lithium project near Harare on the first day. The theme of the conference is 'The Future of Mining in Zimbabwe, Opportunities and Challenges'. The Branch Committee has begun planning for the conference, and potential sponsors are being approached.

\section{Branch Elections}

The annual general meeting, which had been planned for May 2018 to coincide with a Branch event, did not take place due to the inability of the sponsor to host the event. However, a new Branch Committee has been elected for the period July 2018 to June 2019. The members are as follows:

\section{Forthcoming events}

The following three events are planned for the year 2018/2019:

> November 2018: Future of Zimbabwe Mining Industry International Conference

> March 2018: Branch Event

> May 2018: Branch Event and AGM

\section{Financial}

The Branch continues to operate an account under the Chamber of Mines of Zimbabwe, since we have encountered difficulties in opening our own separate account as directed by the SAIMM office. More avenues will be explored in the coming year to make this initiative possible. The Branch had a cash balance in the account of around US\$13 000 as at end June 2018, after paying a deposit of US\$7 500 towards the November 2018 conference venue. Some money from the last international conference (July 2017) was transferred into the main branch account in South Africa. The reconciliation of the 
accounts is still to be finalized.

The Branch is sponsoring the attendance by the Zimbabwe youth development leadership at the main branch youth development meetings in South Africa.

The part-time administrator was sponsored by the Zimbabwe Branch to attend a conference in Cape Town with the SAIMM administration staff. This was part of the training planned for the administrator. The initiative is intended to build more capacity and capability within the Zimbabwe Branch Committee to promote the growth of the SAIMM in Zimbabwe.

A budget for $2018 / 2019$ is being prepared and will be submitted to the SAIMM office in Johannesburg by the end of August 2018.

A budget for the year 2018/2019 is being prepared and will be circulated to the main branch by the end of August 2018.

\subsubsection{Zululand Branch}

C. Mienie, Chairperson

E. Clare

R. Kutama

W. Jordaan

P. Strydom

There is no report for this year.

\section{International liaison}

\section{Portfolio Holder: S. Ndlovu}

There is nothing to report this year.

\section{Key Performance Areas}

\section{To achieve its objectives, the SAIMM}

- Participates in and represents South Africa on bodies such as the Mining, Metals \& Minerals Society (TMS), and together with Mintek on Infacon

> Appoints corresponding members in areas such as Australasia, Botswana, Brazil, Canada, Chile, Europe, the Far East, Ghana, New Zealand, the UK, and the USA, and interacts with sister institutions in other countries to promote international exchange of scientific and technical information.

\subsection{APCOM}

C. Dohm, Chairperson

There is no report for this year.

\subsection{INFACON}

R.T. Jones, Chairperson

I.J. Geldenhuys, Secretary General

The International Ferro-Alloys Congress (Infacon) was founded in South Africa in 1974 by the SAIMM, the National Institute for Metallurgy (NIM, now Mintek), and the Ferro-Alloy Producers' Association (FAPA) when the first Infacon was held in Johannesburg. Infacon events are overseen by an international governance structure that is now known as the International Committee on Ferro-Alloys (ICFA), which has representation from major countries that produce and consume ferro-alloys. ICFA has the primary objectives of promoting the holding of the International Ferro-Alloys Congress every three years in appropriate locations around the world, and ensuring that the high technical standard of papers and presentations is maintained. Mintek provides the secretariat for ICFA.
Infacon has become established as the premier technical conference serving the international ferro-alloys industry. Congresses have been held in twelve different countries around the world. Previous events have taken place in the following locations:

1974: Infacon I - Johannesburg, South Africa

1980: Infacon II - Lausanne, Switzerland

1983: Infacon III - Tokyo, Japan

1986: Infacon IV - Rio de Janeiro, Brazil

1989: Infacon V - New Orleans, USA

1992: Infacon VI - Cape Town, South Africa

1995: Infacon VII - Trondheim, Norway

1998: Infacon VIII - Beijing, China

2001: Infacon IX - Quebec City, Canada

2004: Infacon X - Cape Town, South Africa

2007: Infacon XI - New Delhi, India

2010: Infacon XII - Helsinki, Finland

2013: Infacon XIII - Almaty, Kazakhstan

2015: Infacon XIV - Kyiv, Ukraine

2018: Infacon XV - Cape Town, South Africa

The Fifteenth International Ferro-Alloys Congress (Infacon $\mathrm{XV}$ ) was held at the Century City Conference Centre in Cape Town from 25-28 February 2018, and was attended by 450 delegates from 32 countries. The Congress was co-chaired by Professor Rodney Jones and Professor Hurman Eric. After a cycle of four congresses in the northern hemisphere (New Delhi, India, 2007; Helsinki, Finland, 2010; Almaty, Kazakhstan, 2013; and Kyiv, Ukraine, 2015), it was appropriate that Infacon should return to South Africa at a time of great change in the region.

This Congress reflected a changing industry in a changing world. There have been major structural changes in the ferroalloys industry over the past few years, as companies seek to find the global economic optimum of where and how important metals are produced. For example, in 2012, China replaced South Africa as the leading producer of ferrochromium. More recently, we see further evidence of change in South Africa's new political leadership, and levels of optimism have started improving. The drought in Cape Town emphasized the importance of adapting to a changing climate, and prompted delegates to reflect on how, as responsible citizens of our planet, we can improve the environmental performance and energy efficiency of our industry. South Africa has played a leading role in the global ferro-alloys industry for a long time. Even if the nature of its contribution changes, the country will continue to be a major player in this arena.

Infacon XV covered the major ferro-alloys (especially $\mathrm{FeCr}$ and FeMn) extensively. The primary focus was on technical aspects of production processes, furnaces, and power supplies, but safety, environmental, and legislative aspects were covered too. The topics discussed reflected many of the needs and challenges faced by ferro-alloy producers today.

The peer review process was taken very seriously, and the organizers drew on the expertise and insights of 146 experts from around the world who generously offered constructive criticism and suggestions, as a result of which the papers were improved greatly. About 150 papers were selected from 199 abstracts that were submitted. Each paper was thoroughly reviewed by at least two independent experts in their respective specialist fields. We are very grateful to these reviewers who gave their time freely in undertaking this monumental task, 
and appreciate their valuable technical and editing inputs. We also appreciate the time and effort that the authors put into their papers and presentations.

Infacon is set up on the principle that the sharing of technical information is of great benefit to the industry. The publication of scientific and engineering work is vital. The Infacon series of congresses is well known for the quality of the papers, due largely to the considerable work that is put into the reviewing process. ICFA has a policy of making papers from all Infacon events, current and past, freely available via open access, and these are now available online.

Delegates were pleased to have Infacon return to Cape Town - a city of great scenic beauty and a world heritage site. A welcoming function was held on the evening before the conference at 'On the Rocks' in Bloubergstrand, with a spectacular view of Table Mountain and the sunset over Robben Island. The conference dinner was held at Kirstenbosch National Botanical Garden, accompanied by an extensive and wide-ranging cultural programme of dancing and singing.

At the conclusion of the conference, an African drum, a tangible symbol of Infacon XV, was handed over by Professor Hurman Eric, on behalf of South Africa, to Benjamin Ravary from Norway, as that is where the next Infacon will be held in 2021. Further details regarding the next congress will be available in due course from the conference website at http://infacon16.com

ICFA Contacts:

Chairperson: Professor Rodney Jones rtjones@global.co.za Secretary General: Isabel Geldenhuys IsabelG@mintek.co.za Infacon website: http://www.pyrometallurgy.co.za/Infacon/

\subsection{SAMCODES Standards Committee (SSC)}

$\begin{array}{lr}\text { M, Mullins } & \text { Chair } \\ \text { T. Marshall } & \text { Deputy Chair } \\ \text { S. Moola } & \text { Administrator } \\ \text { A. Donnelly } & \text { Scribe } \\ \text { K. Lomberg } & \text { SAMVAL } \\ \text { K. Redman } & \text { SAMOG } \\ \text { P. Dekker } & \text { SAMESG } \\ \text { S. Magnus } & \text { GSSA } \\ \text { R. Dixon } & \text { JSE } \\ \text { S. Siwela } & \text { SAIMM / CRIRSCO } \\ \text { A. de Bruyn } & \text { (Solid Minerals) } \\ \text { R. Ingram } & \text { Readers Panel } \\ \text { A. Clay (Oil \& Gas) } & \text { ECSA } \\ \text { J. Cato } & \text { SAGC } \\ \text { A. Bals } & \text { IMSSA } \\ \text { L. Koorsse } & \text { SAOGA } \\ \text { N. Kramer } & \text { GASA } \\ \text { C. Dohm } & \text { SohSCO } \\ \text { M. Booysen } & \text { SAICA } \\ \text { G. Grobler } & \text { IASSA } \\ \text { K. Davies } & \text { DMR } \\ \text { B. Williamson } & \text { DMR } \\ \text { M. Tsanwani } & \text { Law Societies of South Africa } \\ \text { S. Mabaso } & \text { General Council of the Bar } \\ \text { O. Moumakwa } & \text { C. Teffo }\end{array}$

\section{Observer Organizations}

P. Rampersadh
G. Botha

M. Kabai SACNASP

K. Motjale Financial Sector Conduct Authority (FCSA)

\section{Strategic direction}

The SSC continues to build on the excellent foundation that has been laid over the past decade, and particularly under the leadership of the immediate past Chair, Tania Marshall.

The SSC has strengthened its relationship with its Patrons, with extended institutes, and with securities exchanges in South Africa and abroad. We have built on our foundation through continuing our strong education and promotion portfolio, through ensuring that our governance procedures are in place and working smoothly, and through promoting the SAMCODES Way, both in South Africa and abroad.

Our relationship with the JSE has been strengthened, particularly through the new mandate of the Readers Panel, and through co-branding with the JSE wherever possible.

\section{SAMCODES Committee activities}

Ken Lomberg, Kelly Redman, and Sarah Magnus continue as Chairs of the SAMREC and SAMVAL Code Committees and the SAMESG Guideline Committee respectively. Peter Dekker is the new Chair of the SAMOG Committee.

\section{SAMREC Committee}

$>$ The Committee continues to engage with the South African Bureau of Standards (SABS) to assist in updating SANS 10320:2004, which is now out of date and out of step with both SAMREC and with international developments. Issues have been raised with respect to content, jurisdiction, copyright, cost, and training, and these are currently ongoing.

> The Code is being critically reviewed for its applicability to possible future technological developments, particularly in reporting the new 'green' minerals such as lithium.

\section{SAMVAL Committee}

> The 'Parked Issues' are being reviewed through a subcommittee, which has developed a position paper which has been widely circulated for comment.

> The Committee continue with the work on registration with statutory bodies.

\section{SAMOG Committee}

> The Committee commented on the 2018 proposed PRMS update and reviewed the impact the update might have on the existing SAMOG Code.

> Discussions were held with the Alberta Securities Commission on the planned update of the COGE handbook (expected in 2018). The impact of the updates on the SAMOG Code will be reviewed.

> A short training course on the reporting systems and SAMOG Code is being prepared, which most likely will be given during the AAPG Convention and Exhibition in Cape Town in November 2018.

\section{Education and promotion}

The SSC continues its high level of Code education and promotion, focusing equally on students, young professionals, and experienced practitioners. Where possible these events are 
organized through the Patrons, and either form part of existing conferences or are stand-alone events.

Educational events continue to be organized for interested parties, such as the JSE, the Institute of Directors of SA, the Council for Geoscience, and the DMR.

The Squirrel Awards through the Investment Analysts Society of South Africa, for the best Public Reporting, are the premier promotion activity on the SSC calendar, were presented on 21 June 2018.

\section{Key activities 2017/18}

> SAIMM: YPC (presentation)

> SAIMM: International Platinum Conference (two presentations)

> GSSA: SAMCODE Compliance and JSE reporting for CPS (three-day workshop)

> SAIMM: Project Valuation workshop (three-day course)

> SAIMM: Advanced SAMREC/SAMVAL (two-day workshop)

> JSE: Valuation for non-technical Professionals (two halfday workshops)

- Two personalized workshops for the DMR (two full days)

> One personalized workshop for the CGS (one full day)

- A short presentation was given at Stats-SA, to encourage compliant reporting of National Accounts and National Inventory data (or at least reporting that does not confuse various local and international reporting systems)

> Geo-Skills Conference (March 2018)

> Global Mineral Resource and Valuation Reporting Standards: Their evolution, convergence and effectiveness. Presentation at Minex Asia, Kazakhstan, April 2018 by M. Mullins.

\section{Organized and proposed activities}

Diamond Reporting Workshop - Tania Marshall

11 June 2018

Junior Indaba Panel discussion - Matt Mullins

June 2018

GSSA/SAMCODES/JSE Reporting Workshop

(Tania Marshall)

28-29 June 2018

Copper Cobalt Conference

(Steven Rupprecht and Matt Mullins

9 July 2018

SAMCODES Workshop at Geocongress

17 July 2018

SAMREC/SAMVAL

Advanced Training Workshop

$16-17$ August 2018

SAMVAL for non-technical

Professionals - SAMVAL Committee/JSE. 5-6 September 2018

Joburg Indaba

October 2018

SAMOG Workshop at AAPG Conference

(Peter Dekker)

4-7 November 2018

International Conference on

Public Reporting in the Extractive Industries

\section{International developments}

CRIRSCO is developing into a strong International force in Reserve and Resource reporting, with 13 current national members. Traditionally SAMREC, one of the founding members, has been represented on the Executive Committee.

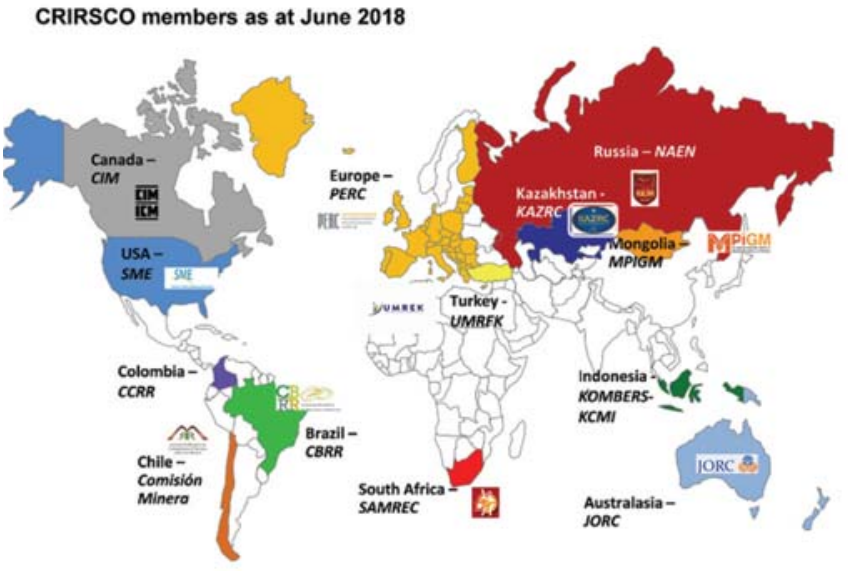

This continues, with Ken Lomberg being the incumbent Deputy Chairperson and future Chairperson. Roger Dixon remains on the CRIRSCO Committee and provides critical long-term continuity. In this way SAMREC will continue to have a material influence on the direction of CRIRSCO.

The annual CRIRSCO meeting is scheduled to take place in London in September 2018. The two main drivers are to increase membership, with some 10 countries interested in becoming part of CRIRSCO. An updated template has been drafted for comment, which can be used to guide new members, to include recent code updates, as well as to provide leadership in critical areas such as environmental and social issues.

IMVAL is developing into a global forum for international coordination and direction of Valuation reporting, and Kelly Redman is the current SAMVAL representative on the Committee. SAMOG has been given Observer status, with Peter Dekker sitting on the Committee.

The third edition of the IMVAL template has been circulated. A number of sub-committees have been formed and ratified by the IMVAL Committee. One of these is the Template Committee, which will look at adding issues such as company valuations, which will be included in the next IMVAL template. There is also Liaison Committee and a Membership Committee.

A desire has been expressed to have a forum for presentation of the various Codes at PDAC next year, which could eventually develop into an annual meeting of all members.

The UNFC continues to drive the evolution of national reporting, with Roger Dixon representing CRIRSCO at its most recent meeting in Geneva. The key outcomes of this meeting are as follows.

> There was a strategic move away from a classification system to a resource management system that supports the 17 Sustainable Development Goals (SDGs).

> There was a definite move towards the green economy rather than a fossil fuel economy. Therefore, there would be more emphasis on specifications for renewable energy resources and anthropogenic resources.

\section{Visit by Chinese Delegation}

The SSC has begun planning for the official visit by the Mineral Resources and Reserves Evaluation Centre of the Ministry of Land and Resources, PR China, for a training visit to South Africa from 14 October to 3 November this year. There will be about 20 senior government officials attending the training 
programme, some of whom will be of Director General level. Attendees will be from the central government and also from the provinces, and will be principally interested in how the SAMREC/SSC Codes work in practice for market reporting, government reporting, and their relationship to trading in mineral rights reporting.

\section{Management and Administration}

\section{Portfolio Holder: S. Ndlovu}

The Secretariat consists of:

Sam Moolla (Manager)

Gugu Charlie (Conference Coordinator)

Camielah Jardine (Head of Conferencing)

Tshepi Letlhaku (Receptionist and Assistant to the Manager)

Dennis Makondesa (Accountant)

Portia Malatji (Accounts Assistant)

Zuliakha Malgas (DTP Operator)

Nazli Mamdoo (Conference Publications Coordinator)

Kelly Matthee (Journal Coordinator)

Yolanda Ndimande (Conference Coordinator)

Prudence Ntumeleng (Membership Assistant)

Anna Panana (Conference Secretary)

Aphathia Sello (Administration Clerk)

Keabetswe Shumba (Membership and Branch Liaison Administrator)

Naomi Wernecke (Communications Coordinator)

The SAIMM, Office Bearers, and Council record their appreciation to the above for their service.

\subsection{Finance}

\section{Portfolio Holder: V.G. Duke}

\section{Highlights}

$>$ Income up by $58 \%$ year on year.

- Expenditure up by only $42 \%$ year on year.

Despite a difficult year, your Institute has recorded an operating surplus of R143k for the 2017/18 financial year (YE2018) against losses over the previous three years.

\section{Income}

Total income amounted to R26m against an annual average of $\mathrm{R} 18.9 \mathrm{~m}$ over the past five years.

Conference revenue grew by $88 \%$ from $\mathrm{R} 11 \mathrm{~m}$ to $\mathrm{R} 21 \mathrm{~m}$. This was due to the committed efforts of your Technical Programmes Committee (TPC) and solid contributions from international conferences like AfriRock, Copper Cobalt, and Infacon. There are unfortunately no international conferences planned for next year, but your Institute's conferences remain world class and are also priced to facilitate aggressive
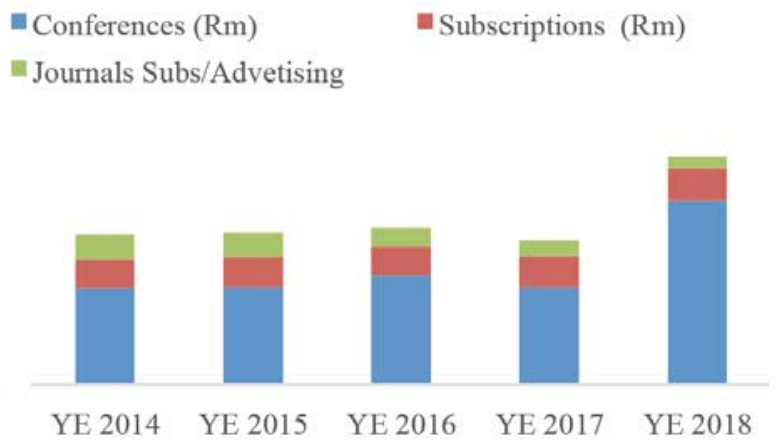

Cost of Sales (Rm) Operating expenses (Rm)

30

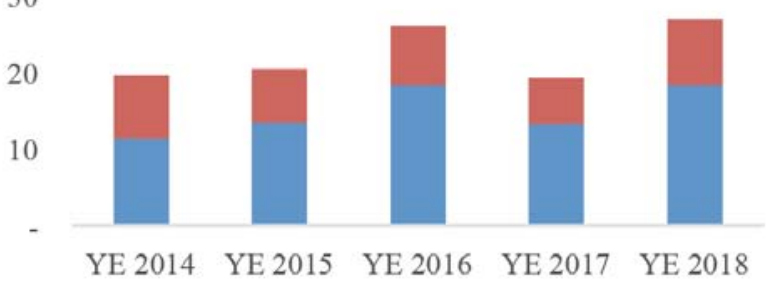

competition in this difficult market.

Income from subscriptions grew by $5 \%$, with the number of paying members now at 5077 . Collections continue to be difficult and 245 members, with fees outstanding for more than two years, were removed from our register. Our annual subscription increases have not exceeded the inflation rate.

Your Institute's debtor's book has also been under considerable strain due to late payments from conference attendees and renewed attention will be given to this during the coming year. Total trade and other receivables stands at $\mathrm{R} 4.1 \mathrm{~m}$ and $\mathrm{R} 3.8 \mathrm{~m}$ of this is due to the debtor's book.

\section{Total Expenditure}

Overall operating expenses and cost of sales have been prudently managed and some difficult cost containment measures are beginning to yield results.

The cost of sales went up by $\mathrm{R} 5.0 \mathrm{~m}$ (38\%), which is much lower than the associated increase in revenue.

Operating expenses were up by $\mathrm{R} 2.6 \mathrm{~m}$ from the previous period, with the larger expenses being attributable to:

> A donation of R242 000 to the Scholarship Trust Fund.

- A 458000 loan write off against the Scholarship Trust Fund.

> A 800000 write off of bad debts with the bulk of this amount being due to non-payment of membership fees.

> A R112 000 contribution to the Global Mining Standards Group (GMG).

\section{Investment Portfolio}

Our investments are critical for both short term stability and the long term sustainability of your Institute. It is pleasing to report that despite market volatility over the past year, the investment portfolio has performed relatively well.

The closing balance was R31.7m as at 31 June 2018; an overall net increase of R1.9m after:

- A fair value adjustment of R3.9m

- Income from dividends of R0.9m

$>$ Income from interest of $\mathrm{R} 0.1 \mathrm{~m}$

$>$ A drawdown of R2.5m.

6

$$
\text { = Investment Income (Rm) }
$$

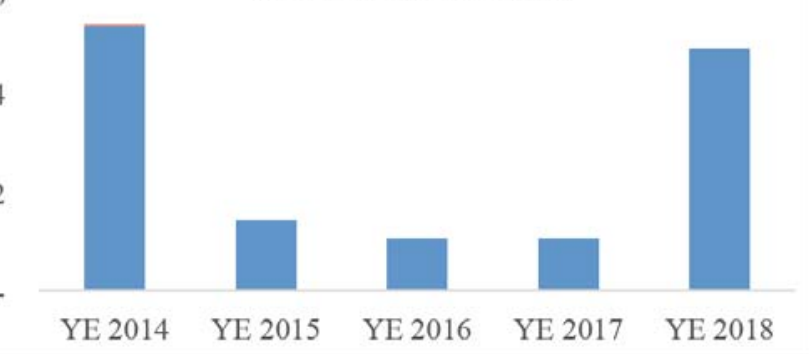


This drawdown followed a significant withdrawal of R5.75m to cover losses during the 2015/16 year and a further drawdown of $\mathrm{R} 2.0 \mathrm{~m}$ during the following year. These were all necessary to finance three years of losses and the operational cash movements over the December holiday periods.

The latest drawdown included R0.5m which was $50 \%$ of an Infacon research fund commitment. The remaining $50 \%$ will be required this coming year.

When looking ahead, there are indications from improved budgeting in the form of a three-year projection of our likely maximum and minimum cash flow requirements, that further funding from our reserves are unlikely to be necessary through to 2021 .

\section{Closing Comments}

In summary, the total surplus for the year stands at R5m a great improvement from last year's deficit of R63 000. Other key metrics from the 2017/18 Financial Statements are provided below:

\begin{tabular}{lccr} 
Heading & 2018 & 2017 & \multicolumn{1}{c}{$\%$} \\
\hline Assets & R38.9m & R33.4m & 16 \\
Equity & R36.0m & R31.4m & 14.7 \\
Liabilities & R $2.9 \mathrm{~m}$ & R $1.9 \mathrm{~m}$ & 52.6 \\
Revenue & R26.0m & R $16.4 \mathrm{~m}$ & 58.5 \\
Cost of Sales & R $18.0 \mathrm{~m}$ & R $13.0 \mathrm{~m}$ & 38.5 \\
Operating Exp. & R $8.6 \mathrm{~m}$ & R $6.0 \mathrm{~m}$ & 43 \\
Operating Surp. & R 0.1m & R $-1.0 \mathrm{~m}$ & -110 \\
Total Surplus & R 5.0m & R $-0.63 \mathrm{k}$ & $\mathbf{8 0 3 7}$
\end{tabular}

On behalf of the Institute, I wish to thank Professor Jim Porter who recently resigned as the Honorary Treasurer, and understand that I have sizeable boots to fill according to the admin staff, who all work very well with him. I would also like to specifically thank Sam Moolla your Office Manager and this wonderful mix of SAIMM staff for their sterling work and for assisting me in picking up the responsibility of Honorary Treasurer.

Your Institute welcomes Genesis Chartered Accountants, who have assumed the Auditor's role with effect from 01 July 2018, and at the same time thanks Robert Kitching for the services that we have enjoyed over recent years.

Finally, we have received excellent returns from our AFC investment and thank Dee Campouroglou (AFC Account Manager) for this.

\section{New Members}

Members

J.D. Ackermann, F.O. Aramide, S.J. Archer, M.C. Bahome, V. Bailey, D. Benson, A. Berghorst, B. Besa, B.J. Brahmapuri Janakiram, M. Carlos, C.G. Chasaya, C. Chilufya, T. Chinhengo, H. Chiswaswa, W. Chitate, B.R. Crompton, E. de Villiers, K. Dikosha, M.S. Dzimba, Y. Fan, J. Gnoinski, T.L. Grewar, B. Gwavava, M.H. Hanson, G. Hawlitschek, M.T. Hlambelo, C. Hlangabeza Khumalo, H. Joubert, J.C. Kanku,

M.K.M. Kaonda, J. Kapobe, B.T. Katiyo, L.Q. Kebatsetse, P. Kegaisitse, J.M. Koorts, S.G. Lavery, J.W.D Lumb, G.C. Luzendu, T.E. Magama, J. Makgatho, L.P. Makhubu, N.B. Maledi, B. Mamogale, T.R. Marshall, J. Masua, J. Meadows, P.B. Moletsane, Z.C. Msimang, J. Mufara, B. Muleya, J.B. Mulunda, O. Munachoonga, P.N.C. Mutsinya, I. Muzinda, E. Mwampokota, D. Naidoo, P. Ngwenya,
F.C. Nieuwenhuys, P. Nkhwalume, L. Noveve, J.O. Okeniyi, T.T. Phakathi, R.T. Rakotomalala, N. Rampersad, P. Selema, K.S. Shandavu, B.B Sithole, W. Tsanulani, E. Vascotto, D. Zeelie, A. Zezekwa, W.H. Black, E.R. Brümmer, J. Deacon, O. Mahenga, S. Mulonda, R. Reddy.

\section{Associates}

K.A. Clarke, G.G. Dembetembe, H.R. Muhali, A.P. Ogunode, R.A. Wildenboer, S. Biswas, S.L. Burger, R. L. Chosi, N.H. Dire, N.Z. Dzimunya, B.R. Hietbrink, C. Mazala, H.T. Mushonga, R. Nyirenda, R. Phiri, L.P. Tsibane, U. Hall, M. Lekobotja, T.V. Mwayi, J. Scholtz, M.S. Gerke, T.R. Monepya, M.F. Msibi, T.L. Mathevula, C. Chivazve, L. Ranieri, K. Dzwiti, K. Basvi, T. Masuku, K.A. Shame, S. Soqinase, V. Zitsenga, R.L. Sakaran, A.M. Le Grange, P.J.A. Bezuidenhout, N. Chipilingu, M.A. Mello, K.V. Morudu, J.J. Munnik, C. Swart, R.G. van der Colff.

\section{Associates from Conferences}

M.M.N. Amwaama, M.N. Amwele, H.Z. Bakare, W. Botha, B. Bowman, N.G. Chauke, S.T. Chingowe, C. Chipare, T.K. Chivese, H.P. De Wet, M.B. Dlame, C. Dobola, C.R. Eimann, M. Ferentinou, J.M. Githiria, J.H. Goosen, E.D.C. Hingston, P. Kaluzi, T. Lebeta, R. Leo, S.M. Mabaso, N.G. Mafurutu, C. Mahanyele, K. Mahuma, B. Makichi, T. Mapaura, T. Masango Chabiamupeu, M. Mathuthu, B. Matoba, E.O. Mensah, C. Mhindu, N.D. Mokhine, U. Mokoena, P. Moleko-Boyce

\section{Students}

S.N.N. Akawa, B.T. Amadhila, O.S. Aron, N. Bakasa, T.P. Baloi, H. Baloyi, L.R. Baloyi, S.B. Baloyi, M.T. Banda, N. Bhebhe, H. Bhudhe, L.V. Chambara, S.C. Chanda, A. Chapfika, X.V. Chauke, R. Chauke, A. Chazarira, I.S. Chenjera, L. Chidanhika, K. Chifamba, P. Chifura, N.C. Chikonye, A.M. Chimombe, A.A.V. Chioreso, B.K. Chipunza, T.B. Chiura, K.P. Chivamba, T. Chivlera, A.A. Chiwara, L.M. Choma, B.K.S. Cidibi, L.M. Daobanes, J.N. Dlamini, M.M. Dlamini, E. Duve, V.S. Dzarira, R. Fombe, T F. Gabashane, G.R. Gariseb, N. Gina, B. Godama, T.I. Gota, T.J. Gotore, Z.P. Gqweta, T.E. Gumede, H.A. Gumede, A.T. Guzha, S.L. Hadebe, M. Hlongwa, S. Hove, A. Ile, C. Kamonja, A.T. Kapuma, J.N. Kayembe, N. Kekana, D. Kganane, M.M. Khodumo, M.K. Khoele, R.B. Khosa, A.T. Khoza, K.S. Khumalo, F.C. Khupe, M. Kombora, N.J. Kopanye, R.S. Kupa, W.D. Kureya, A.H. Kusano, T. Kuvarega, H.A. Laewamo, K.K. Langa, O. Laquela, P.D. Lefu, R.M. Lekaka, M.T. Lekhuleni, M.M. Lekwadu, R.J. Lerotholi, N. Lesoga, M. Letsoalo, G. Lunga, O.M. Luvhengo, S.T. Mabaso, M.D. Mabelane, T. Maboko, T.S.I. Mabuoa, M. Madihlaba, N. Madlala, W. Madyambwa, T. Maera, D. Mafukidze, N. Mafumo, B.N. Mahlangu, R.N. Mahlangu, S.T. Makazhe, G.S. Malefo, F.S. Maluleke, M.B. Mampuya, T. Mangope, P. Manika, H.D. Mantsonyane, K. Manyelo, T.D. Mapfumo, A. Maqude, R.M. Marume, N.S. Masango, N.L. Maseko, P.M. Mashaba, K.K. Mashifane, M.J. Mashilo, M.E. Masinga, O.N. Masirika, R. Masuvhelele, G. Masvanhise, L.N. Maswanganye, M.T. Maswaya, C.M. Matete, D.C. Mathaba, P.N. Mathabatha, M.D. Matlakala, N.J. Matsimane, R.T. Matsokotere, M. Mavenkere, A. Mawango, N. Mawela, S.N. Mayisa, A. Mbiri, L.N. Mbiza, F.M.N. Mfeka, Y.A. Mgwebi, S. Michaels, K.E. Mochologi, T.M. Mohale, M.E. Moitsi, K.M. Mojalefa, T. Mokgomola, Q.M.P. Mokgopo, D.M. Molefe,G.M. Molepo, N.C. Moloi, 
A.G. Moloto, K. Monene, M.R. Morajane, T.E. Morakile, R.P. Moreki, E.O. Mosako, L.A. Mosima, P.W. Motshegare, P.D. Motsoane, D.C. Moyaha, A.T. Moyo, R.Q. Mpahlele, M.P. Mphaphathi, T. Mphephu, A. Mponya, A.A. Mqoqi, K. Msibi, L.N. Msipha, H.J. Msweli, S. Mtatabikwa, S.S. Mthanti, C. Mtombo, B.T. Mtungwa, J.A. Muchemwa, B.J. Mudema, R.Y. Mudereri, G.N. Mudzembweh, T. Mugova, M.T. Mukubonda, M.C. Mulala, K. Munyai, T. Mupambwi, M.R. Mupini, C.S. Mupudzi, I.S. Murove, B.T. Murowanidzwa, R.L. Mutepe, R. Mutsiwa, G. Mutukura, G. Muzamba, C. Muziringa, B. Mvindo, B. Mwewa, S. Mxhonywa, F.P.N. Nampweya, M.M. Napo, P.H.V. Ncube, P. Ncube, T. Ncube, V. Ncube, O. Ndabangaye, C. Ndebele, S.M. Ndebele, T. Neka, S.B. Nemaramba, N. Netshaulu, K. Ngani, S.P. Ngidi, T. Ngobeni, R.E. Ngoveni, T.T. Ngwenya, K.D. Nhongo, S. Nkabinde, B. Nkoana, P.C. Nkogatse, M. Nkopodi, N.G. Nkosi, S. Nkunkuma, P.R. Nyoni, S.K. Nzimande, T.J. Olaniyi, B.T. Pamire, P. Pedzisi, R.R. Phahlane, M.M.K. Phetla, M.K. Phiri, D.J. Poopedi, P. Pudikabekwa, C.K.S. Ramafoko, E. Ramohlale, M. Ramudzwagi, S. Ramusi, P.J. Raolane, L.A. Raphala, G.D. Raselabe, K.T. Rathupetsane, A. Ratshalingwa, T.R. Sadomba, M.E. Sebola, L. Sekwati, K. Seotsanyana, K. Serumula, S.S. Shabangu, T. Shabangu, D. Shabangu, E.I. Shawelaka, N. Shindi, M. Shirinda, L. Shoko, C.T. Shumba, M.W. Siaga, B. Sibanda, M. Sibanda, V. Sibanda, T.M. Sigauke, M.C. Simango, T. Simango, M.L. Sithole, R.S. Tadzavshe, B.D. Tandana, B.T. Taruwedzera, R. Thanyani, T.K. Thathane, A.T. Thela, T. Thlomani, I.S. Thusi, T.J.N. Tladi, P.M.G. Thabi, D.K. Togara, K.M. Tshegameno, O.M.R. Tshipa, M.C. Umba, E.O. Umeh, D. Viljoen, T. Witbooi, M. Xulu, K.L. Youlton, N. Zhou, A. Zimema, L. Zulu, M.K. Zulu, W. Zvangayidza.

\section{Resignations}

\section{Fellows}

M. Ram Reddi, D.M. Walters, P.D. Scott, J. Dixon, J.P. Bloemsma.

\section{Members}

M.L. Petrick, N.C. Barnard, L. Sherman, U. Drews, C.M. Digby, M.E. Berger, N.T. Middleton, L.P.V. De Villiers, M. Stewart, L.S. Maphaha, N. Reddy, M.S. Hunt, B. Elezaj, K.T. Luden, R. Khatri, D. Shah, B. Mulcahy, C. du Plessis, E.R. Els, S.B. Mbonani, K. Nkole.

\section{Associates}

D. Govender, E.N. Nkwamba, E.L. De Beer, L.E. Lottering, A. Sewards, T. Pillay, E. Moodley, M. S. Motlhabane, C.B. Masango, R.L. Mojela, B. Schoevaerts, M.T. Mamina, O. Biribauer, L.B. Sekhokoane, G. Panopoulos, G.M. Pearson, C.F. Vos, W.V. Aarde, G. Panopoulos, D.J. Robinson, A. van der Westhuizen.

\section{Retired Fellows}

J.P. Deetlefs, I.P. Douglas

\section{Company Affiliates}

Bell Equipment Limited, SMS Group Technical Services South Africa (Pty) Ltd, Goba (Pty) Ltd.

\section{Members transferred to Higher Grade}

Transfer from Retired Fellow to Fellow

E.J. de Jager.

\section{Transfer from Member to Fellow}

M.J. Burnett, W. Assibey-Bonsu, E.R. Klue, M. Mostert,

B. Genc, H. Jacobs, M.F. Breed, D.R. De Wit, N. Singh.

\section{Transfer from Associate to Member}

W.H. Pretorius, M. Baxter, R. Minango, P.F. de Almeida Hopp.

\section{Transfer from Student to Member \\ C.E. Dekker.}

\section{Transfer from Student to Associate}

A.P. Mlombo, D.L. McKay, C. Mwachikorera, A.T. Nhapi,

T.W. Gwishiri.

\section{Members who retired \\ Fellows}

M.A. Ford, S.P. Moult, B. Prout, R.G. Wadley, D.R. Betton, J.A. Johnson, E.J. Magri, L.G.D. Napier, M.R. Sharpe, J.C. Steenkamp, M.A.J. Button, S.M. Gould, P.R.S. van Dorssen, I. Matunhire, C.T. Morley, A.W. Dougall, C. Van Zyl, F.W. Taylor, P.A. Townsen.

\section{Members}

M.J. Boylett, T.R. Curr, P.P. Jourdan, S. Wade, R.I. Skelton, F.T. Kruger, M.A. Smith, D.A.J. Starley, N. Wilson, P.M. Craven, P. Roger, D.S. Du Toit van den Bergh, R.J. van der Schyff, J.A. Richards, A.G.W. Knock, R.J. van der Schyff, M.H.G. Heyns, J.P.W. Fisher, J.F. Kotze, R. Roux.

\section{Members who were re-admitted \\ Re-admitted as a Member}

R.J. Mostert, S.K. Makuza, P.L. Sibiya, H. Mutonowana, T. Punzul, M.T. Hlambelo, A. Lubbe, S. Monnanyana, K.I. Phalakatshela, W.H. Pretorius, D.P. Roberts, M.E.M. Mahlambi, Z. Setete, J. Winnan, F.K. Mduli, R.E.L. Pobe, F. Kwangwari.

\section{Re-admitted as an Associate}

K.T. Kekana, T. Matabane, M. Ravhura, S.F. Manjengwa M. Munkombwe.

\section{Re-admitted as a Student}

M.C. Apua.

Members who were re-instated

\section{Re-instated as a Member}

A.M. Berejena, M. Mahlangu, D.S. Mathebula, L.B. Mukumbi, M.M. Motloung, J.M. Musasaidzwa, E. Mnisi.

\section{Re-instated as an Associate}

G.A. Khonkhobe, F.J.J. Fourie, M.C. Moyo, T. Macha, S.V. Mkhatshwa, J.M. Snyman, T. Nyazaya, M. Pelser.

\section{Deceased}

Honorary Life Fellows

O.K.H. Steffen.

\section{Retired Members}

J.M. Fowlds.

\section{Members}

D.J. Bradshaw, M. Salamon, K. McMillan.

\section{Associates}

R. Sirwali. 
The SAIMM would like to thank the following sponsors for their support throughout the year

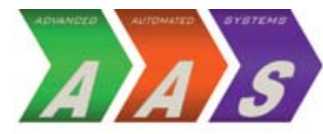

ADVANCED

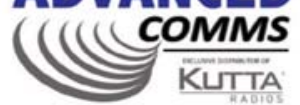

AVENE accutrak

IF YOU CAN MEASURE IT, YOU CAN MANAGE IT
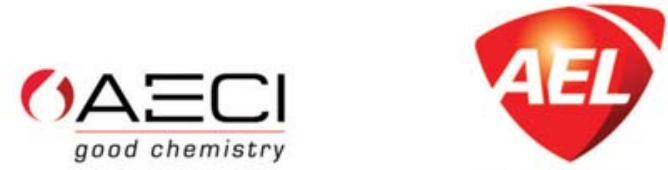

Mining Services

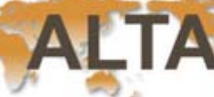

ALTA

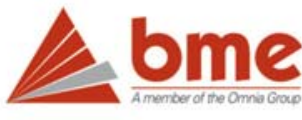

BANNERMAN
BOOYCO
ELECTRONICS

COMETVA s.A.

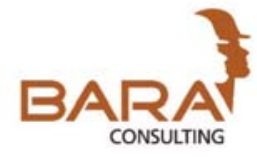

SNF CHEMQUEST

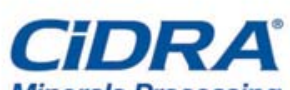

Minerals Processing

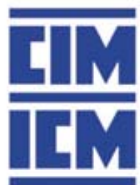

PS.

DANGO \& DIENENTHAL

(SOUTHERN AFRICA) (PTY) (LTD)

\section{s}


The SAIMM would like to thank the following sponsors for their support throughout the year

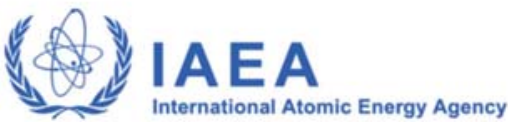

IDS

GeoRadar

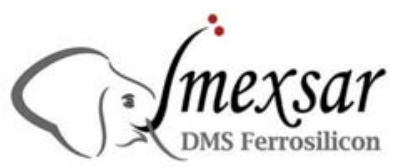

LANXESS

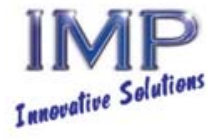

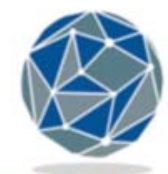

KIYO Solutions

\section{MACCAFERRI} AFRICA

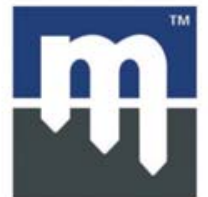

MASTER DRILLING

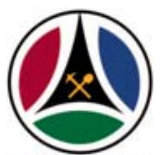

MHSC

Mine Health and Safety Council

\section{MEI}

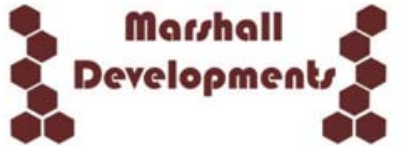

MASIMO

\section{MULTOTEC}

Murray Murray \& Roberts \&Roberts

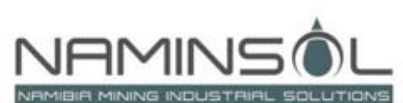

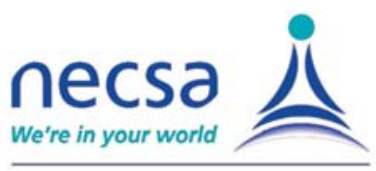

South African Nuclear Energy Corporation SOC Limited

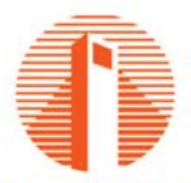

New Concept Mining Support for the World's Deepest Mines
NTre Logistics 公

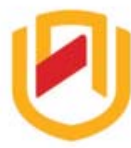

TAMIBIA UTIVERSITY

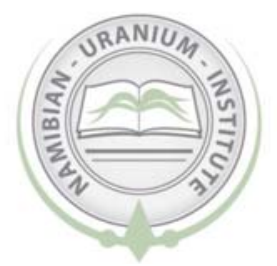


The SAIMM would like to thank the following sponsors for their support throughout the year

\section{盟0HMS \\ OPTRON \\ $\Omega$ B $\varepsilon \triangle \varnothing \bar{\Lambda} \sigma$ \\ Outotec}

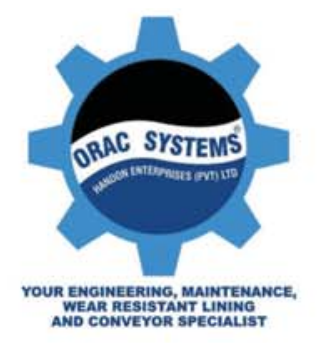

\section{PORTNEX}

INTERNATIONAL
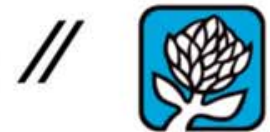

Protea

Chemicals

Purolite

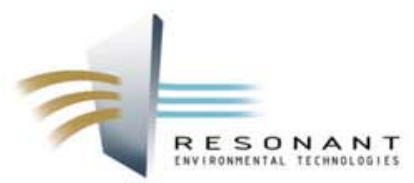

REUTECH

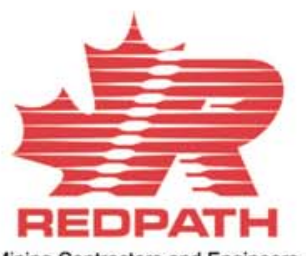

Mining Contractors and Engineers

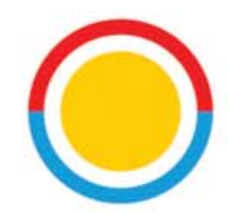

RioTinto

Rössing Uranium

Working for Namibia

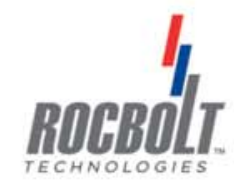

RIPASSO ENERGY

Roskill

SAMPEC

SANDVIK

(《Sedna
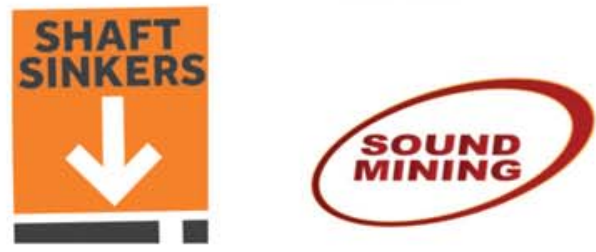

च= srik consulting
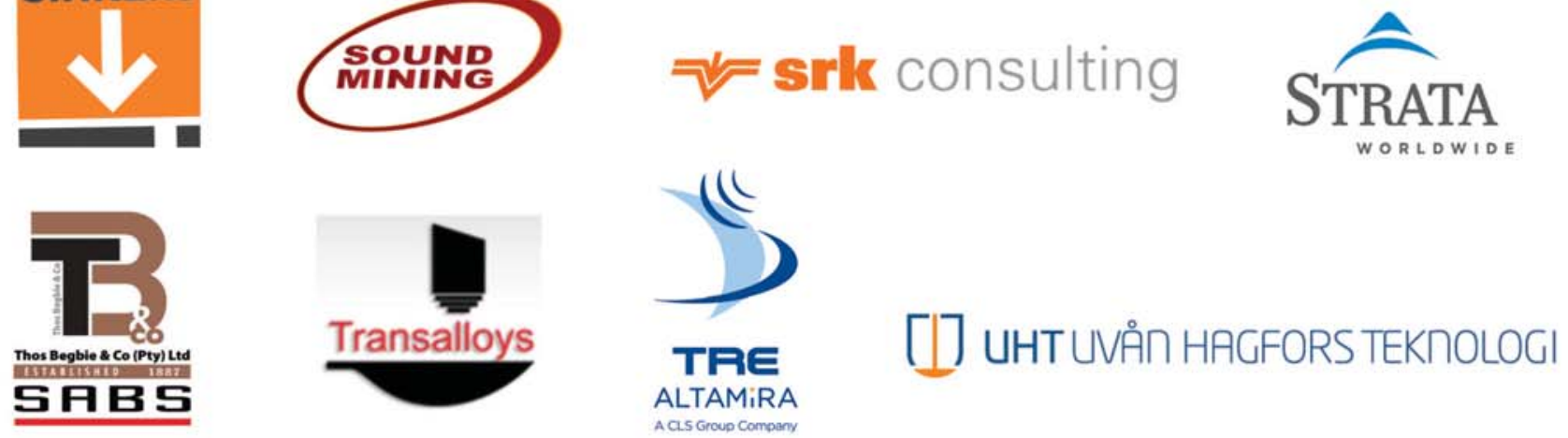

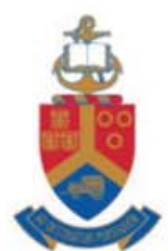

UNIVERSITEIT VAN PRETORIA UNIVERSITY OF PRETORIA YUNIBESITHI YA PRETORIA

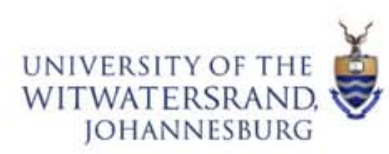

CHENIET METALLURGICAL IENGINEERING

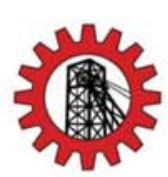

SCHOOL OF MINING ENGINEERING

UNIVERSITY OF THE WITWATERSRAND 